\title{
Cardiotoxicity Induced by Protein Kinase Inhibitors in Patients with Cancer
}

\author{
Aleksandra Grela-Wojewoda ${ }^{1, *(\mathbb{D} \text {, Renata Pacholczak-Madej }}{ }^{1,2}$, Agnieszka Adamczyk ${ }^{3}$, Michał Korman ${ }^{4}$ \\ and Mirosława Püsküllüoğlu ${ }^{1}$ (C)
}

check for

updates

Citation: Grela-Wojewoda, A.;

Pacholczak-Madej, R.; Adamczyk, A.; Korman, M.; Püsküllüoğlu, M. Cardiotoxicity Induced by Protein Kinase Inhibitors in Patients with Cancer. Int. J. Mol. Sci. 2022, 23, 2815. https://doi.org/10.3390/ ijms23052815

Academic Editors: Daniela Sorriento and Guido Iaccarino

Received: 31 January 2022

Accepted: 2 March 2022

Published: 4 March 2022

Publisher's Note: MDPI stays neutral with regard to jurisdictional claims in published maps and institutional affiliations.

Copyright: () 2022 by the authors Licensee MDPI, Basel, Switzerland. This article is an open access article distributed under the terms and conditions of the Creative Commons Attribution (CC BY) license (https:// creativecommons.org/licenses/by/ $4.0 /)$.
1 Department of Clinical Oncology, Maria Sklodowska-Curie National Research Institute of Oncology, Kraków Branch, Garncarska 11, 31-115 Kraków, Poland; renata.pacholczak@uj.edu.pl (R.P.-M.); mira.puskulluoglu@gmail.com (M.P.)

2 Department of Anatomy, Jagiellonian University Medical College, 31-008 Kraków, Poland

3 Department of Tumour Pathology, Maria Sklodowska-Curie National Research Institute of Oncology, Kraków Branch, Garncarska 11, 31-115 Kraków, Poland; agnieszka.adamczyk@onkologia.krakow.pl

4 Faculty of Medicine, Jagiellonian University Medical College, 31-008 Kraków, Poland; michal.korman@student.uj.edu.pl

* Correspondence: aleksandra.grela-wojewoda@onkologia.krakow.pl; Tel.: +48-1263-48350

\begin{abstract}
Kinase inhibitors (KIs) represent a growing class of drugs directed at various protein kinases and used in the treatment of both solid tumors and hematologic malignancies. It is a heterogeneous group of compounds that are widely applied not only in different types of tumors but also in tumors that are positive for a specific predictive factor. This review summarizes common cardiotoxic effects of KIs, including hypertension, arrhythmias with bradycardia and QTc prolongation, and cardiomyopathy that can lead to heart failure, as well as less common effects such as fluid retention, ischemic heart disease, and elevated risk of thromboembolic events. The guidelines for cardiac monitoring and management of the most common cardiotoxic effects of protein KIs are discussed. Potential signaling pathways affected by KIs and likely contributing to cardiac damage are also described. Finally, the need for further research into the molecular mechanisms underlying the cardiovascular toxicity of these drugs is indicated.
\end{abstract}

Keywords: cardiotoxicity; molecular mechanisms of cardiac damage; protein kinase inhibitors; targeted treatment; cancer

\section{Introduction}

The incidence of cancer has been increasing worldwide. Data show that cancer may become the leading cause of death in some countries in the 21st century. In 2017, there were 24.5 million new cancer cases and 9.6 million cancer-related deaths, as compared with 12.7 million and 7.4 million, respectively, in 2008 [1,2]. In women, the most common type of cancer is breast cancer, followed by lung, cervical, and colorectal cancer [2]. In men, the highest incidence was reported for lung cancer, followed by colorectal, gastric, and prostate cancer [2]. The incidence of cancer depends on the country, the advancement of climate change, socioeconomic conditions, the level of education, lifestyle and life expectancy, and the organization of the healthcare system [3,4].

Recently, there has been significant progress in oncologic treatment. For many years, chemotherapy and hormone therapy have been the major options for systemic cancer treatment. However, advances in the field of basic sciences and improved understanding of carcinogenesis have led to the development of modern agents that are now widely available, namely, molecularly targeted drugs and immunotherapy. Thus, the current options for systemic cancer treatment include chemotherapy, hormone therapy, targeted drugs, and immunotherapy, commonly used in combination. Among targeted therapies, protein kinase inhibitors (KIs) are a growing group of drugs used in the majority of cancer indications, 
including lung, breast, colorectal, kidney, liver, or thyroid cancer, but also melanoma, soft tissue sarcoma, gastrointestinal stroma tumor (GIST), and various hematological malignancies [5,6] New strategies have changed the treatment paradigm in many types of cancer, which are now considered to be chronic diseases rather than fatal diseases with a short life expectancy. However, new treatment modalities, including protein KIs come at the cost of unavoidable side effects, including cardiotoxicity.

Chemotherapy and molecularly targeted drugs can cause cardiac dysfunction, which affects patient survival and the quality of life. The most common type of cardiotoxicity is symptomatic or asymptomatic left ventricular (LV) dysfunction, which can be induced both by classic chemotherapy (such as anthracyclines) and by molecularly targeted drugs [7-9]. The monitoring of left ventricular function in clinical practice is based on the evaluation of left ventricular ejection fraction (LVEF) during echocardiographic examination and electrocardiogram (ECG) recording.

Cardiovascular diseases and cancer are the most common health problems in highly developed countries. The optimal strategy for modern oncologic treatment should be based on a comprehensive approach to oncologic and cardiology patients.

The aim of this review was to explore molecular mechanisms of cardiotoxicity induced by protein KIs in patients with cancer and to summarize the frequency and clinical significance of the most common cardiac toxicities caused by KIs.

\section{Families of Protein Kinases}

Protein kinases are enzymes responsible for the phosphorylation of proteins that are involved in various signaling pathways. Phosphorylation results in cell proliferation, migration, survival, and differentiation. Thus, any disturbances in this process are key elements of carcinogenesis and result in the transformation of the proto-oncogene into the oncogene. The discovery of KIs has changed the paradigm of treatment for various malignancies. As of January 2022, the Food and Drug Administration and the European Medicines Agency have approved more than 60 KIs for use in the therapeutic setting.

Protein KIs can be classified into several families depending on the structure and ligand: epidermal growth factor receptor (EGFR) inhibitors; vascular endothelial growth factor receptor (VEGFR) tyrosine kinase inhibitors; v-raf murine sarcoma viral oncogene homolog B (BRAF) 1/2 inhibitors; mitogen-activated protein kinase kinases 1 and 2 (MEK) inhibitors; anaplastic lymphoma kinase (ALK) inhibitors; Bruton tyrosine kinase (BTK) inhibitors; phosphoinositide 3-kinase (PI3K) inhibitors; cyclin-dependent kinase (CDK) 4/ 6 inhibitors; Janus kinases (JAK) inhibitors; BCR-ABL tyrosine kinase inhibitors; FMS-like tyrosine kinase-3 (FLT3) inhibitors; and stem cell factor receptor/platelet-derived growth factor receptor (KIT/PDGFRA) inhibitors (Figures 1 and 2). Specified molecular targets and therapeutic indications currently available in the European Union are presented in Table $1[5,10]$.

Additionally, KIs are classified according to their biochemical properties and specific mechanism of action. This classification has evolved over the decades. Initially, Dar and Shokat [6] proposed three types of inhibitors depending on the way they bind to the adenosine triphosphate pocket (i.e., to its active conformation type I, inactive type II, and non-adenosine triphosphate competitive inhibitor or allosteric inhibitor type III). Subsequently, allosteric inhibitors were divided into two classes (type III (allosteric inhibitors) and type IV (substrate-directed inhibitors)) [11]. Lambda and Gosh [12] distinguished also type $\mathrm{V}$ inhibitors, which span two regions of the protein kinase domain, and type VI inhibitors, which form covalent adducts. In this review, we classified KIs according to the Roskoski classification, but the subcategories were omitted for simplicity [13]. Some of the KIs were thus unclassified and were labeled as "no data" in Table 1. 


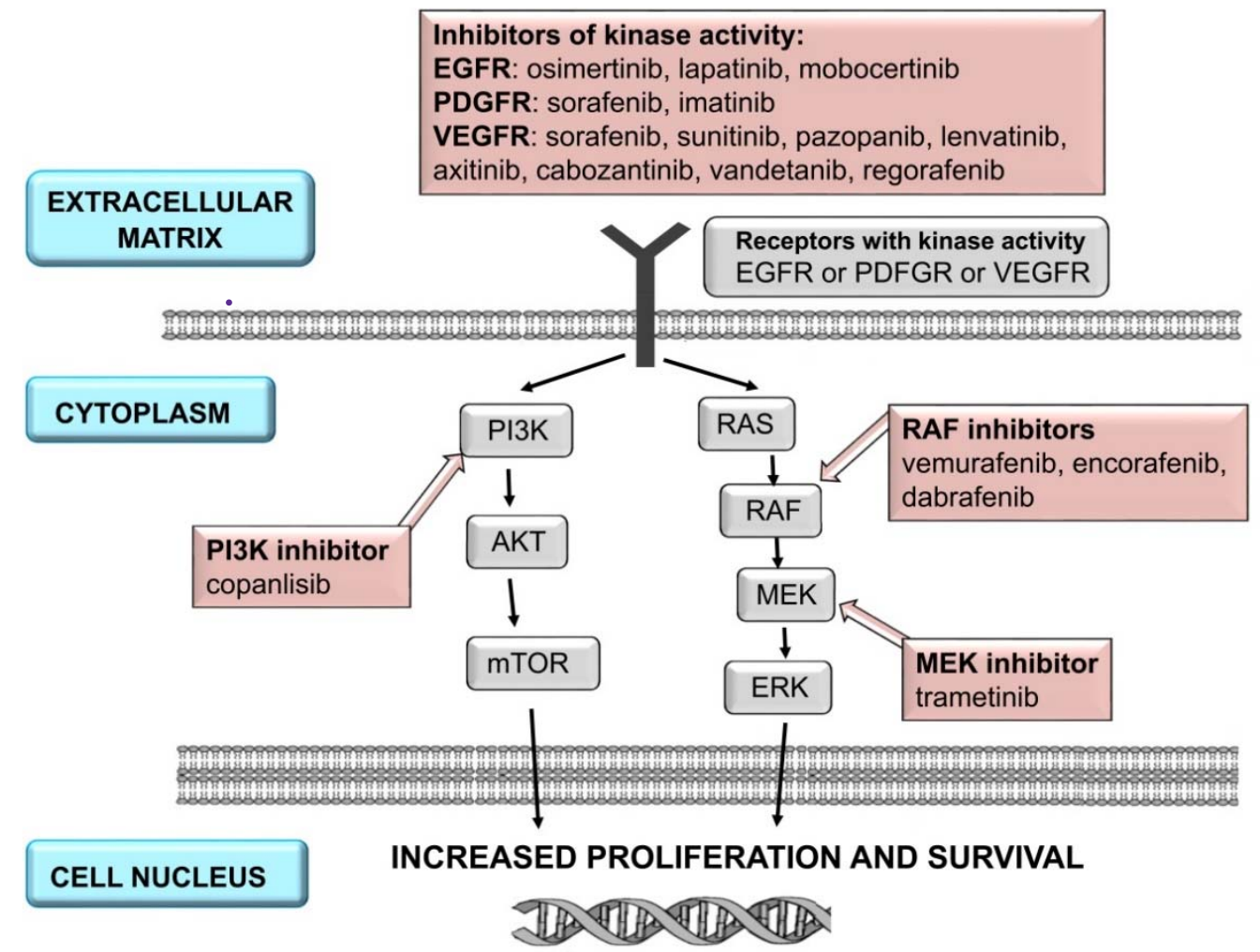

Figure 1. A simplified scheme of signal transmission in cell and selected target points: EGFR, MEK, PGDFR, PI3K, RAF, and VEGFR for molecularly targeted drugs (protein kinase inhibitors) [14-18].

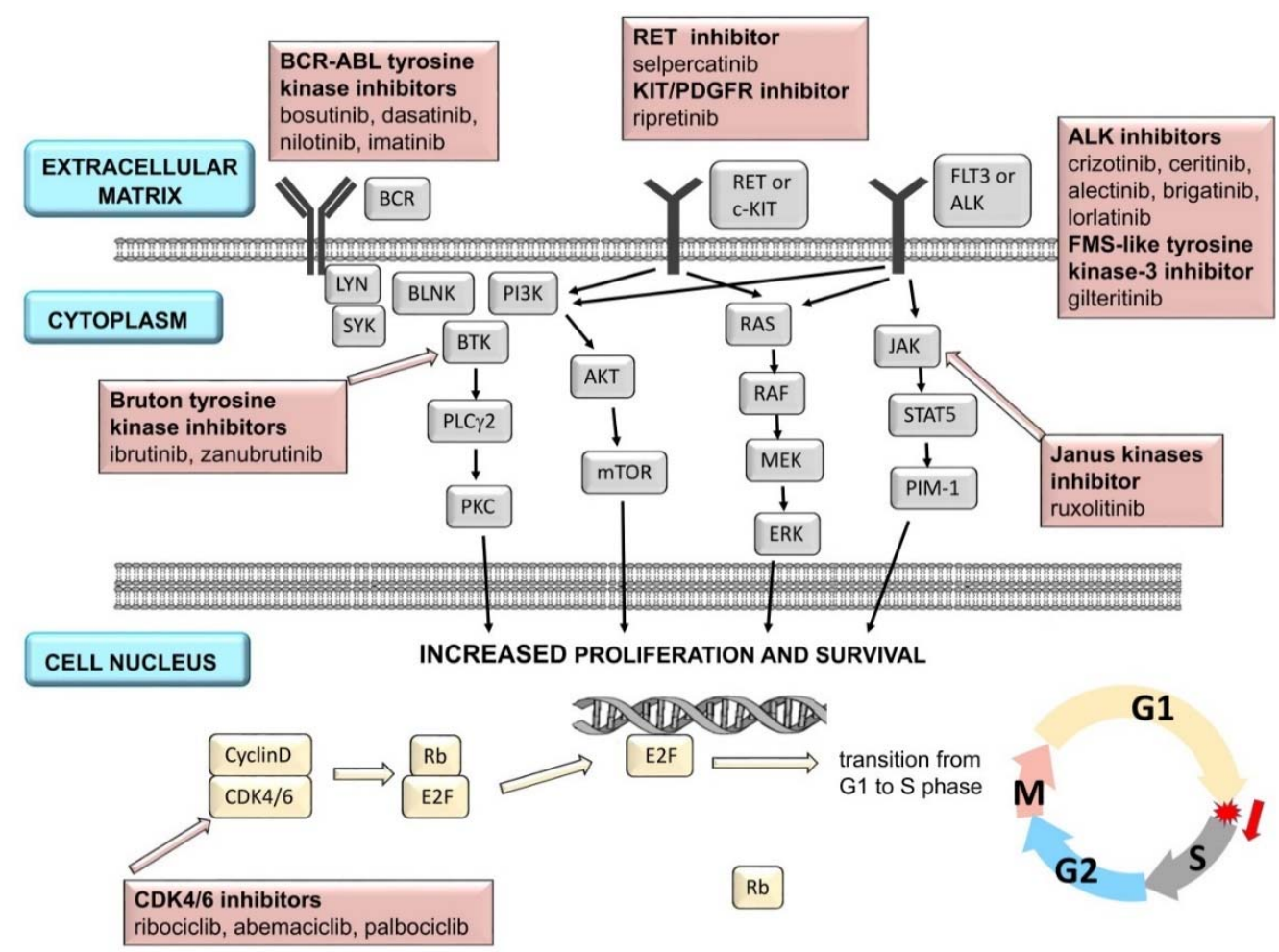

Figure 2. A simplified scheme of signal transmission in cell and selected target points: ALK, BCRABL, Bruton tyrosine kinase, CDK 4/6, FMS-like tyrosine kinase-3, Janus kinases, KIT/PDGFR, and RET for molecularly targeted drugs (protein kinase inhibitors) [19-24]. 
Table 1. Molecular targets and therapeutic indications for protein kinase inhibitors approved for use in adult patients with cancer by the European Medicines Agency (EMA) unless otherwise specified (compiled on the basis of the Summary of Product Characteristics as of January 2022).

\begin{tabular}{|c|c|c|c|c|c|}
\hline Inhibitor & Subtype & Molecular Targets & Therapeutic Indications & Type and Incidence of Cardiotoxicity \& & Class $^{\wedge}$ \\
\hline \multicolumn{6}{|c|}{ Vascular endothelial growth factor receptor tyrosine kinase inhibitors } \\
\hline Sunitinib & Receptor TKI & $\begin{array}{l}\text { PDGFR } \alpha, \text { PDGFR } \beta, \\
\text { VEGFR-1, -2, -3, KIT, } \\
\text { FLT3, CSF-1R, RET }\end{array}$ & $\begin{array}{l}\text { 1. GIST after treatment failure/imatinib } \\
\text { intolerance } \\
\text { 2. mRCC-metastatic setting } \\
\text { 3. pNET-unresectable/metastatic }\end{array}$ & $\begin{array}{ll}\text { 1. } & \text { Hypertension }(44.7 \%) \\
\text { 2. } & \text { QTc prolongation }(0.5 \%) \# \\
\text { 3. Cardiomyopathy }(3-15 \%) \\
\text { 4. Arterial and venous } \\
\text { thromboembolic events }(1.4 \%)\end{array}$ & $\mathrm{I} / \mathrm{II}$ \\
\hline Pazopanib & Receptor TKI & $\begin{array}{l}\text { PDGFR } \alpha, \text { PDGFR } \beta \\
\text { VEGFR-1, }-2,-3, \text { KIT }\end{array}$ & $\begin{array}{l}\text { 1. mRCC-first-line treatment or after } \\
\text { prior cytokine therapy } \\
\text { 2. Advanced soft tissue } \\
\text { sarcomas-second-line treatment or } \\
\text { progression within } 12 \text { months after } \\
\text { prior (neo)adjuvant therapy (certain } \\
\text { subtypes) }\end{array}$ & $\begin{array}{ll}\text { 1. } & \text { Hypertension }(41 \%) \\
\text { 2. } & \text { QTc prolongation }(<1 \%) \\
\text { 3. } & \text { Cardiomyopathy }(6.7 \%) \\
\text { 4. } & \text { Arterial and venous } \\
& \text { thromboembolic events }(3 \%)\end{array}$ & I \\
\hline Lenvatinib & Receptor TKI & $\begin{array}{c}\text { PDGFR } \alpha, \text { VEGFR-1, }-2 \\
-3, \text { KIT, RET, FGFR-1, } \\
-2,-3,-4\end{array}$ & $\begin{array}{l}\text { 1. Differentiated thyroid carcinoma } \\
\text { refractory to radioactive iodine } \\
\text { 2. Advanced HCC-first-line treatment } \\
\text { 3. Advanced endometrial } \\
\text { carcinoma-with pembrolizumab, after } \\
\text { prior platinum-containing } \\
\text { chemotherapy }\end{array}$ & $\begin{array}{ll}\text { 1. } & \text { Hypertension }(48 \%) \\
\text { 2. } & \text { QTc prolongation }(9 \%) \\
\text { 3. } & \text { Cardiomyopathy }(<1 \%) \\
\text { 4. } & \text { Arterial and venous } \\
& \text { thromboembolic events }(5 \%)\end{array}$ & $\mathrm{I} / \mathrm{II}$ \\
\hline Sorafenib & $\begin{array}{l}\text { Multikinase } \\
\text { inhibitor }\end{array}$ & $\begin{array}{l}\text { PDGFRß, VEGFR-2, }-3, \\
\text { CRAF, BRAF, } \\
\text { KIT, FLT3 }\end{array}$ & $\begin{array}{l}\text { 1. HCC-metastatic setting } \\
\text { 2. mRCC-after prior interferon } \\
\text { alfa/interleukin-2 therapy or unsuitable } \\
\text { for such treatment } \\
\text { 3. Differentiated thyroid carcinoma } \\
\text { refractory to radioactive iodine }\end{array}$ & $\begin{array}{l}\text { 1. Hypertension }(17-29 \%) \\
\text { 2. QTc prolongation (rare) } \# \\
\text { 3. Cardiomyopathy (rare) } \\
\text { 4. Arterial and venous } \\
\text { 5. Myomboembolic events }(1.4 \%) \\
\text { 5. Myocardial ischemia }(2.9 \%)\end{array}$ & II \\
\hline Axitinib & Receptor TKI & VEGFR-1, $-2,-3$ & $\begin{array}{l}\text { 1. mRCC-after prior sunitinib or cytokine } \\
\text { therapy }\end{array}$ & $\begin{array}{l}\text { 1. Hypertension }(40 \%) \\
\text { 2. QTc prolongation (rare) } \# \\
\text { 3. Cardiomyopathy }(1.8 \%)^{\#} \\
\text { 4. Arterial and venous } \\
\text { thromboembolic events }(2.8 \%)^{\#}\end{array}$ & II \\
\hline
\end{tabular}

1. mRCC:

- first-line treatment as a single agent in intermediate/

poor-risk patients 1. Hypertension $(>25 \%)$ \#

MET, VEGFR, AXL, RET, ROS1, TYRO3, MER, KIT, TRKB,

FLT3, TIE-2
- first-line treatment in combination with nivolumab

second-line treatment after prior anti-VEGF therapy

2. HCC - after prior sorafenib treatment
2. Arterial and venous thromboembolic events (1-10\%) ${ }^{\#}$ 
Table 1. Cont.

\begin{tabular}{|c|c|c|c|c|c|}
\hline Inhibitor & Subtype & Molecular Targets & Therapeutic Indications & Type and Incidence of Cardiotoxicity ${ }^{\&}$ & Class $^{\wedge}$ \\
\hline & & & Bruton tyrosine kinase inhibitors & & \\
\hline \multirow[t]{2}{*}{ Ibrutinib } & \multirow[t]{2}{*}{ Bruton TKI } & \multirow[t]{2}{*}{ BTK } & $\begin{array}{l}\text { 1. MCL-relapsed/refractory } \\
\text { 2. CLL: } \\
\text { - first-line treatment as a single agent } \\
\text { or with rituximab/obinutuzumab } \\
\text { - } \\
\text { subsequent lines as a single agent or } \\
\text { in combination with rituximab and } \\
\text { bendamustine }\end{array}$ & \multirow{2}{*}{$\begin{array}{l}\text { 1. Hypertension }(2-80 \%) \\
\text { 2. Atrial fibrillation }(13 \%) \\
\text { 3. Ventricular arrhythmias }(1 \%) \# \\
\text { 4. }\end{array}$} & \multirow[t]{2}{*}{ VI } \\
\hline & & & $\begin{array}{l}\text { 3. Waldenström } \\
\text { macroglobulinemia-first-line } \\
\text { treatment for patients unsuitable } \\
\text { for chemo-immunotherapy or } \\
\text { subsequent lines }\end{array}$ & & \\
\hline Zanubrutinib * & Bruton TKI & BTK & 1. MCL-after at least two prior therapies & $\begin{array}{l}\text { 1. Hypertension }(5-12 \%) \\
\text { 2. Atrial flutter/ fibrillation }(2 \%)\end{array}$ & $\mathrm{n} / \mathrm{d}$ \\
\hline \multicolumn{6}{|c|}{ Phosphoinositide 3-kinase inhibitors } \\
\hline Copanlisib * & $\begin{array}{l}\text { PI-3K kinase } \\
\text { inhibitor }\end{array}$ & PI-3K & $\begin{array}{l}\text { 1. Follicular lymphoma-after at least one } \\
\text { prior therapy }\end{array}$ & 1. Hypertension $(54.8 \%)$ & $\mathrm{n} / \mathrm{d}$ \\
\hline \multicolumn{6}{|c|}{ Janus kinases inhibitors } \\
\hline Ruxolitinib & $\begin{array}{l}\text { Janus kinases } \\
\text { inhibitor } \\
\text { (JAKs) }\end{array}$ & JAK-1, -2 & $\begin{array}{l}\text { 1. Myelofibrosis } \\
\text { 2. Polycythemia vera-after prior } \\
\text { hydroxyurea treatment }\end{array}$ & 1. Hypertension $(>10 \%)^{\#}$ & I \\
\hline \multicolumn{6}{|c|}{ Anaplastic lymphoma kinase inhibitors } \\
\hline Crizotinib & $\begin{array}{l}\text { ALK-receptor } \\
\text { TKI }\end{array}$ & ALK, HGFR, ROS-1 & $\begin{array}{l}\text { 1. NSCLC-ALK-positive in the first or } \\
\text { subsequent lines of treatment } \\
\text { 2. NSCLC-ROS-1 positive }\end{array}$ & $\begin{array}{l}\text { 1. Bradycardia }(0.5-70 \%) \\
\text { 2. QTc prolongation }(1-3 \%) \\
\text { 3. Cardiomyopathy }(1 \%){ }^{\#}\end{array}$ & I \\
\hline Ceritinib & $\begin{array}{l}\text { ALK_receptor } \\
\text { TKI }\end{array}$ & ALK & $\begin{array}{l}\text { 1. NSCLC-ALK-positive in the first-line } \\
\text { treatment or after prior crizotinib } \\
\text { therapy }\end{array}$ & $\begin{array}{l}\text { 1. Bradycardia }(2.3 \%)^{\#} \\
\text { 2. QTc prolongation }(1-3 \%) \\
\text { 3. Cardiomyopathy (rare) }\end{array}$ & I \\
\hline Alectinib & $\begin{array}{l}\text { ALK-eceptor } \\
\text { TKI }\end{array}$ & ALK, RET & $\begin{array}{l}\text { 1. NSCLC-ALK-positive in the first-line } \\
\text { treatment or after prior crizotinib } \\
\text { therapy }\end{array}$ & $\begin{array}{l}\text { 1. Bradycardia }(8 \%) \\
\text { 2. Cardiomyopathy (rare) }{ }^{\#}\end{array}$ & $\mathrm{n} / \mathrm{d}$ \\
\hline Brigatinib & $\begin{array}{l}\text { ALK-eceptor } \\
\text { TKI }\end{array}$ & ALK, ROS-1, IGF-1R & $\begin{array}{l}\text { 1. NSCLC-ALK-positive in the first-line } \\
\text { treatment or after prior crizotinib } \\
\text { therapy }\end{array}$ & $\begin{array}{ll}\text { 1. } & \text { Hypertension }(20 \%) \\
\text { 2. } & \text { Bradycardia }(8 \%) \\
\text { 3. } & \text { QTc prolongation }(>1 \%)^{\#} \\
\text { 4. } & \text { Cardiomyopathy (rare) }{ }^{\#}\end{array}$ & $\mathrm{n} / \mathrm{d}$ \\
\hline Lorlatinib & $\begin{array}{l}\text { ALK_receptor } \\
\text { TKI }\end{array}$ & ALK, ROS-1 & $\begin{array}{l}\text { 1. NSCLC-ALK-positive in the } \\
\text { second-line treatment after prior } \\
\text { ceritinib/alectinib or in subsequent } \\
\text { lines after prior crizoninib and at least } \\
\text { one other ALK inhibitor }\end{array}$ & $\begin{array}{l}\text { 1. Hypertension }(13 \%)^{\#} \\
\text { 2. Bradycardia }(8 \%) \\
\text { 3. QTc prolongation }(0.7 \%){ }^{\#} \\
\text { 4. Cardiomyopathy (rare) }\end{array}$ & $\mathrm{n} / \mathrm{d}$ \\
\hline \multicolumn{6}{|c|}{ RET inhibitors } \\
\hline Selpercatinib & $\begin{array}{l}\text { RET_receptor } \\
\text { TKI }\end{array}$ & $\begin{array}{l}\text { RET, VEGFR-1, }-2,-3, \\
\text { FGFR-1, }-2,-3\end{array}$ & $\begin{array}{l}\text { 1. NSCLC-RET-positive second-line } \\
\text { treatment after prior immunotherapy } \\
\text { and/or platinum-based chemotherapy } \\
\text { 2. Thyroid cancer-RET-positive } \\
\text { second-line treatment after prior } \\
\text { sorafenib and/or lenvatinib }\end{array}$ & $\begin{array}{l}\text { 1. Hypertension }(14-21 \%) \\
\text { 2. QTc prolongation }(6-15 \%)\end{array}$ & $\mathrm{n} / \mathrm{d}$ \\
\hline \multicolumn{6}{|c|}{ Epidermal growth factor receptor inhibitors } \\
\hline Osimertinib & Receptor TKI & $\begin{array}{l}\text { EGFR, TKI-resistant } \\
\text { mutation T790M }\end{array}$ & $\begin{array}{l}\text { 1. NSCLC - with activating } \\
\text { EGFR mutations: } \\
\text { - } \quad \text { adjuvant treatment in stage IB-IIIA } \\
\text { after complete resection } \\
\text { - } \quad \text { first-line treatment in } \\
\text { advanced/metastatic setting } \\
\text { - } \quad \text { EGFR T790M mutation-positive } \\
\quad \text { advanced/metastatic setting }\end{array}$ & $\begin{array}{l}\text { 1. QTc prolongation }(1.2-11 \%) \\
\text { 2. Cardiomyopathy }(3-5 \%)\end{array}$ & $\mathrm{n} / \mathrm{d}$ \\
\hline
\end{tabular}


Table 1. Cont.

\begin{tabular}{|c|c|c|c|c|c|}
\hline Inhibitor & Subtype & Molecular Targets & Therapeutic Indications & Type and Incidence of Cardiotoxicity ${ }^{\&}$ & Class $^{\wedge}$ \\
\hline Lapatinib & Receptor TKI & EGFR, HER2 & $\begin{array}{l}\text { 1. Metastatic breast cancer HER2-positive } \\
\text { - after prior therapy with } \\
\text { anthracyclines, taxanes, } \\
\text { and trastuzumab in } \\
\text { metastatic setting: } \\
\text { - } \quad \text { in HR-negative patients in } \\
\text { combination with trastuzumab after } \\
\text { prior trastuzumab with } \\
\text { chemotherapy } \\
\text { - in HR-positive patients in } \\
\text { combination with aromatase } \\
\text { inhibitor without indications for } \\
\text { chemotherapy }\end{array}$ & $\begin{array}{l}\text { 1. QTc prolongation (rare) }{ }^{\#} \\
\text { 2. Cardiomyopathy }(2.2 \%)\end{array}$ & I \\
\hline Mobocertinib * & $\begin{array}{l}\text { Kinase inhibitor } \\
\text { of EGFR }\end{array}$ & $\begin{array}{c}\text { EGFR exon } \\
20 \text { insertion mutation }\end{array}$ & $\begin{array}{l}\text { 1. NSCLC with EGRF exon } 20 \text { insertion } \\
\text { mutation after prior platinum-based } \\
\text { chemotherapy }\end{array}$ & $\begin{array}{l}\text { 1. QTc prolongation }(1.2-11 \%) \\
\text { 2. Cardiomyopathy }(2.7 \%)\end{array}$ & $\mathrm{n} / \mathrm{d}$ \\
\hline \multicolumn{6}{|c|}{ BRAF/MEK inhibitors } \\
\hline Vemurafenib & $\begin{array}{l}\text { Inhibitor of } \\
\text { RAF kinases }\end{array}$ & RAF & $\begin{array}{l}\text { 1. Metastatic melanoma } \\
\text { BRAF V600 positive }\end{array}$ & $\begin{array}{l}\text { 1. QTc prolongation }(1-10 \%)^{\#} \\
\text { 2. Cardiomyopathy }\end{array}$ & I \\
\hline Encorafenib & $\begin{array}{l}\text { Inhibitor of } \\
\text { RAF kinases }\end{array}$ & RAF & $\begin{array}{l}\text { 1. Metastatic melanoma BRAF } \\
\text { V600 positive in combination with } \\
\text { binimetinib } \\
\text { 2. mCRC BRAF V600 positive-as a } \\
\text { second-line treatment in combination } \\
\text { with cetuximab }\end{array}$ & $\begin{array}{l}\text { 1. QTc prolongation }(0.7-2.5 \%)^{\#} \\
\text { 2. Cardiomyopathy }(1-10 \%)^{\#}\end{array}$ & $\mathrm{n} / \mathrm{d}$ \\
\hline Dabrafenib & $\begin{array}{l}\text { Inhibitor of } \\
\text { RAF kinases }\end{array}$ & RAF & $\begin{array}{l}\text { 1. Metastatic melanoma BRAF } \\
\text { V600 positive as monotherapy or in } \\
\text { combination with trametinib } \\
\text { 2. Adjuvant treatment of melanoma BRAF } \\
\text { V600 positive in stage III after complete } \\
\text { resection in combination with } \\
\text { trametinib } \\
\text { 3. NSCLC BRAF V600 positive in } \\
\text { combination with trametinib }\end{array}$ & $\begin{array}{l}\text { 1. QTc prolongation }(3 \%)^{\#} \\
\text { 2. Cardiomyopathy }(6 \%)^{\#}\end{array}$ & II \\
\hline Trametinib & MEK inhibitor & MEK $1 / 2$ & $\begin{array}{l}\text { 1. Metastatic melanoma BRAF } \\
\text { V600 positive as monotherapy or in } \\
\text { combination with trametinib } \\
\text { 2. Adjuvant treatment of melanoma BRAF } \\
\text { V600 positive in stage III after complete } \\
\text { resection in combination with } \\
\text { trametinib } \\
\text { 3. NSCLC BRAF V600 positive in } \\
\text { combination with dabrafenib }\end{array}$ & 1. Cardiomyopathy $(11 \%)$ & III \\
\hline \multicolumn{6}{|c|}{ Cyclin-dependent kinase $4 / 6$ inhibitors } \\
\hline Ribociclib & $\begin{array}{c}\text { CDK } \\
4 / 6 \text { inhibitor }\end{array}$ & $\mathrm{CDK} 4 / 6$ & $\begin{array}{l}\text { 1. Metastatic breast cancer HR-positive, } \\
\text { HER2-negative in combination with an } \\
\text { aromatase inhibitor, or fulvestrant as a } \\
\text { first-line treatment or a second-line } \\
\text { treatment after prior endocrine therapy }\end{array}$ & 1. QTc prolongation (7-16\%) & $\mathrm{n} / \mathrm{d}$ \\
\hline Abemaciclib & $\begin{array}{c}\text { CDK } \\
4 / 6 \text { inhibitor }\end{array}$ & CDK $4 / 6$ & $\begin{array}{l}\text { 1. Metastatic breast cancer HR-positive, } \\
\text { HER2-negative in combination with an } \\
\text { aromatase inhibitor, or fulvestrant as a } \\
\text { first-line treatment or a second-line } \\
\text { treatment after prior endocrine therapy }\end{array}$ & 1. QTc prolongation (very rare) ${ }^{\#}$ & $\mathrm{n} / \mathrm{d}$ \\
\hline Palbociclib & $\begin{array}{c}\text { CDK } \\
4 / 6 \text { inhibitor }\end{array}$ & CDK $4 / 6$ & $\begin{array}{l}\text { 1. Metastatic breast cancer HR-positive, } \\
\text { HER2-negative in combination with an } \\
\text { aromatase inhibitor, or fulvestrant as a } \\
\text { first-line treatment or a second-line } \\
\text { treatment after prior endocrine therapy }\end{array}$ & 1. QTc prolongation (very rare) ${ }^{\#}$ & I \\
\hline
\end{tabular}


Table 1. Cont.

\begin{tabular}{|c|c|c|c|c|c|}
\hline Inhibitor & Subtype & Molecular Targets & Therapeutic Indications & Type and Incidence of Cardiotoxicity \& & Class $^{\wedge}$ \\
\hline \multicolumn{6}{|c|}{ BCR-ABL tyrosine kinase inhibitors } \\
\hline Bosutinib & Receptor TKI & $\begin{array}{l}\text { BCR-ABL, Src, Lyn and } \\
\text { Hck, PDGF, c-KIT }\end{array}$ & $\begin{array}{l}\text { 1. CML Ph-positive newly diagnosed in a } \\
\text { chronic phase or after prior TKI in a } \\
\text { chronic/blast phase }\end{array}$ & $\begin{array}{l}\text { 1. QTc prolongation }(0.5 \%){ }^{\#} \\
\text { 2. Fluid retention }(1 \%)\end{array}$ & $\mathrm{I} / \mathrm{II}$ \\
\hline Dasatinib & Receptor TKI & $\begin{array}{l}\text { BCR-ABL, c-KIT, } \\
\text { PDGFR- } \$\end{array}$ & $\begin{array}{l}\text { 1. CML Ph-positive newly diagnosed in a } \\
\text { chronic phase or after prior imatinib in a } \\
\text { chronic/accelerated/ } \\
\text { blast phase } \\
\text { 2. ALL and lymphoid blast CML in a } \\
\text { second-line treatment }\end{array}$ & $\begin{array}{ll}\text { 1. } & \text { QTc prolongation }(1 \%) \\
\text { 2. } & \text { Cardiomyopathy }(1.6 \%) \\
\text { 3. } & \text { Fluid retention }(1 \%)\end{array}$ & I \\
\hline Nilotinib & Receptor TKI & BCR-ABL & $\begin{array}{l}\text { 1. CML Ph-positive newly } \\
\text { diagnosed in a chronic phase } \\
\text { or after prior imatinib in a } \\
\text { chronic/accelerated phase }\end{array}$ & $\begin{array}{l}\text { 1. QTc prolongation }(<5 \%)^{\#} \\
\text { 2. Cardiomyopathy }(<5 \%)^{\#}\end{array}$ & II \\
\hline \multirow{4}{*}{ Imatinib } & \multirow{4}{*}{ Receptor TKI } & & $\begin{array}{l}\text { 1. CML Ph-positive: } \\
\text { - chronic phase for patients } \\
\text { without indications for bone } \\
\text { marrow transplant } \\
\text { - chronic phase after failure of } \\
\text { interferon-alfa therapy, or in an } \\
\text { accelerated phase or blast crisis }\end{array}$ & \multirow{4}{*}{$\begin{array}{l}\text { 1. Cardiomyopathy }(1-2 \%) \\
\text { 2. Fluid retention }(1 \%)\end{array}$} & \multirow{4}{*}{ II } \\
\hline & & $\begin{array}{l}\text { BCR-ABL, c-KIT, } \\
\text { CSF-1R, PDGFR } \alpha,-\beta \\
\text { DDR- } 1,-2\end{array}$ & $\begin{array}{l}\text { 2. ALL Ph-positive first-line treatment in } \\
\text { combination with chemotherapy, } \\
\text { relapsed/refractory as monotherapy } \\
\text { 3. Myelodysplastic/myeloproliferative } \\
\text { disease with PRGFR rearrangements } \\
\text { 4. Advanced hypereosinophilic syndrome } \\
\text { and/or chronic eosinophilic leukemia } \\
\text { with FIP1L1-PDGFR rearrangement } \\
\text { 5. GIST KIT (CD117)-positive: }\end{array}$ & & \\
\hline & & & $\begin{array}{ll}\text { - } & \text { metastatic setting } \\
\text { - } & \text { adjuvant setting at significant } \\
\text { risk of relapse }\end{array}$ & & \\
\hline & & & $\begin{array}{l}\text { 6. Dermatofibrosarcoma } \\
\text { protuberans-unresectable/metastatic }\end{array}$ & & \\
\hline \multicolumn{6}{|c|}{ KIT/PDGFR inhibitors } \\
\hline Ripretinib & Receptor TKI & $\begin{array}{l}\text { KIT, PDGFR } \alpha,-1, \\
\text { TIE-2, VEGFR2, BRAF }\end{array}$ & $\begin{array}{l}\text { 1. GIST after prior three-line treatment } \\
\text { including imatinib }\end{array}$ & 1. Cardiomyopathy $(1.2 \%-2.6 \%)$ & $\mathrm{n} / \mathrm{d}$ \\
\hline \multicolumn{6}{|c|}{ FMS-like tyrosine kinase- 3 inhibitors } \\
\hline Gilteritinib & $\begin{array}{l}\text { Protein kinase } \\
\text { inhibitor }\end{array}$ & FLT3, AXL & $\begin{array}{l}\text { 1. AML with FLT3 mutation- } \\
\text { relapsed/refractory }\end{array}$ & 1. Fluid retention $(24 \%)$ & $\mathrm{n} / \mathrm{d}$ \\
\hline
\end{tabular}

$\mathrm{n} / \mathrm{d}$, no data; ${ }^{*}$ EMA approval is anticipated; compiled on the basis of the Food and Drug Administration label; For references, see the main text; ` Adapted from [13]; \# Complied on the basis of the Food and Drug Administration label; \& For references, see the main text unless otherwise specified.

\section{Cardiotoxicity of Oncologic Drugs}

Cardiac dysfunction related to cancer therapies has several manifestations, from an asymptomatic reduction in LVEF to chronic heart failure. Classic chemotherapy leads to irreversible cardiomyocyte damage $[7,25]$. The mechanism of anthracycline-induced irreversible heart damage has been extensively studied. The analysis of myocardial biopsy enhanced the understanding of the structural damage caused by these drugs. The formation of free radicals and the induction of oxidative stress destroy the myocardial ultrastructuremicrofibril architectonics is disrupted, and the vacuolation and apoptosis of cardiac cells are observed. Initially, these changes may be asymptomatic; however, in some patients, symptoms of heart failure can develop dynamically even many years after the end of the oncologic treatment. Nevertheless, modern molecularly targeted agents (e.g., antiangiogenic KIs) act by changing the energetic pathways of cardiomyocytes and the metabolism of contractile proteins, usually resulting only in temporary heart dysfunction. The clinical 
consequences of this transitory disorder remain unclear [17,26]. Four types of cardiotoxicity have been described $[8,9,27]$ :

Acute cardiotoxicity-It occurs rarely, manifests immediately after the first drug administration, and is dose-independent. Its symptoms include hypotony, arrhythmias, and myocardial ischemia. It is usually reversible after discontinuation of drug infusion.

Subchronic cardiotoxicity - It occurs rarely, and its onset is observed in the first weeks of treatment with high doses of drugs. It usually manifests with myocarditis or pericarditis (e.g., after anthracyclines administration).

Early-onset chronic cardiotoxicity-It develops within a few weeks after discontinuation of treatment and manifests as progressive heart failure.

Late-onset chronic cardiotoxicity-It develops many years after the end of the treatment and leads to heart failure.

A new classification of chemotherapy-related cardiac dysfunction (CRCD) was established after the introduction of modern oncologic agents [28]:

Type I CRCD-irreversible (e.g., after anthracycline administration)

Type II CRCD—potentially reversible, induced by new-generation human epidermal growth factor receptor 2 (HER2)-targeted agents and KIs and is potentially reversible.

Chemotherapy usually comprises several cytostatic agents which might be administered concurrently with targeted agents; therefore, oncologists should consider their possible synergistic toxicity.

\section{Molecular Mechanisms of Cardiotoxicity of Selected Kinase Inhibitors}

The mechanism of KI-induced cardiotoxicity is not fully understood. Examples of KIs with their cardiotoxic effects and the underlying molecular and cellular pathways are presented in Table 2 [29-33]. Generally, the mechanisms of cardiac toxicity can be divided into on-target and off-target mechanisms [33]. On-target mechanisms occur when the inhibition of a molecule by KIs causes an anticancer effect in malignant cells but also leads to toxicity in normal cells. On the other hand, off-target mechanisms occur when KIs inhibit one kinase in malignant cells, causing an anticancer effect, and other kinases in normal cells, leading to cardiac toxicity.

Table 2. Cardiotoxicity caused by selected kinase inhibitors together with suggested underlying mechanisms $[29,30,34-36]$.

\begin{tabular}{|c|c|c|c|}
\hline Kinase Inhibitor & Cardiotoxicity & Suggested Mechanism & Reference \\
\hline $\begin{array}{l}\text { TKIs used in } \\
\text { kidney cancer }\end{array}$ & Hypertension & $\begin{array}{c}\text { VEGFR inhibition } \\
\text { NO and } \mathrm{PGI}_{2} \text { synthesis inhibition } \\
\text { Increase in ET-1 concentration } \\
\text { Vasoconstriction } \\
\text { Capillary rarefaction } \\
\text { Reduction in vessel density }\end{array}$ & [34] \\
\hline Ibrutinib & $\begin{array}{l}\text { Ischemic heart disease } \\
\text { Hypertension } \\
\text { Bradyarrhythmias/atrial } \\
\text { fibrillation }\end{array}$ & $\begin{array}{c}\text { VEGFR2 inhibition } \\
\text { NO formation inhibition } \\
\text { Endothelial disfunction } \\
\text { Vascular remodeling } \\
\text { Inhibition of Src kinase } \\
\text { Downregulation of PI3K-Akt pathway } \\
\text { Cardiac fibrosis }\end{array}$ & {$[29,37]$} \\
\hline Copanlisib & Hypertension & $\begin{array}{l}\text { Mechanism remains unclear } \\
\text { Vasoconstriction due to inhibition of PI3K } \\
\text { (in the endothelium) suspected }\end{array}$ & {$[38,39]$} \\
\hline Crizotinib & Sinus bradycardia & $\begin{array}{l}\qquad \mathrm{I}_{\mathrm{f}} \text { inhibition } \\
\text { Reduced current density of } \mathrm{HCN} 4\end{array}$ & [36] \\
\hline
\end{tabular}


Table 2. Cont.

\begin{tabular}{|c|c|c|c|}
\hline Kinase Inhibitor & Cardiotoxicity & Suggested Mechanism & Reference \\
\hline Ponatinib & Myocardial infarction & $\begin{array}{c}\text { AKT signaling pathway inhibition } \\
\text { ERK inhibition } \\
\text { Apoptosis induction }\end{array}$ & {$[30]$} \\
\hline Dabrafenib & Cardiomyopathy & $\begin{array}{l}\text { ERK inhibition } \\
\text { Lower protection against oxidative stress }\end{array}$ & {$[40,41]$} \\
\hline Trametinib & Cardiomyopathy & $\begin{array}{l}\text { ERK inhibition } \\
\text { Lower protection against oxidative stress } \\
\text { CD47 transcription stimulation (inhibition of NO production) } \\
\text { "Two-hit" hypothesis }\end{array}$ & {$[40,42]$} \\
\hline Ribocyclib & qTc prolongation & $\begin{array}{l}\text { Mechanism remains unclear } \\
\text { Probably not due to CDK } 4 / 6 \text { inhibition } \\
\text { The role of metabolites suspected }\end{array}$ & {$[43]$} \\
\hline Imatinib & $\begin{array}{l}\text { Fluid retention } \\
\text { Cardiomyopathy }\end{array}$ & $\begin{array}{c}\text { Mitochondrial dysfunction: reduction in mitochondrial } \\
\text { membrane potential, cytochrome c release into the cytosol } \\
\text { Activation of the ER stress response } \\
\text { Cellular ATP content reduction }\end{array}$ & {$[35]$} \\
\hline
\end{tabular}

KIs (especially tyrosine kinase inhibitors [TKIs]) inhibit numerous molecular pathways, and various factors contribute to the induction of hypertension. One of the hypotheses is that the inhibition of vascular endothelial growth factor and platelet-derived growth factor receptor (PDGFR) activity results in reduced production of nitric oxide (NO) in the vascular endothelium. On the other hand, a decrease in endothelial NO concentrations leads to a disruption of the endothelin function and an increase in peripheral resistance, which induces a rise in blood pressure [44-46]. A decrease in urinary nitrite excretion and a decrease in the concentration of NO metabolites were observed in patients treated with TKIs, which supports this theory $[47,48]$. There are ongoing studies evaluating the role of other vasoactive factors in inducing arterial hypertension in patients treated with KIs. These other factors include prostaglandins, the renin-angiotensin-aldosterone system, thromboxane, and the effect of KIs on sympathetic nervous system stimulation [47-49].

KIs affect the cardiac conduction system by blocking the cardiac channels, leading to bradyarrhythmia (e.g., atrioventricular blocks, QTc prolongation) and tachyarrhythmia (e.g., atrial fibrillation, supraventricular tachycardia) [32,36,50]. One of the on-target mechanisms underlying the development of arrhythmia can be PI3K blockage. It leads to a rise of persistent sodium current and a reduction in L-type calcium and potassium current as well as QTc prolongation [33]. An example of an off-target mechanism leading to arrhythmia is ibrutinib-induced inhibition of Tec protein tyrosine kinase responsible for cardioprotective function by regulating the PI3K-Akt pathway [29,33].

Left ventricular dysfunction and heart failure may occur as a result of mitochondrial damage, alterations in cardiac energy balance, and contractile protein dysfunction $[7,25]$. According to one hypothesis, the inhibition of PDGFR and other tyrosine kinase receptors in cardiomyocytes, which determines their functioning and survival, disrupts the normal response of the myocyte to hypertensive stress [51,52]. Other authors emphasized the importance of the ribosomal S6 kinase family, as it determines cardiomyocyte survival by inhibiting the phosphorylation of apoptosis-activating factors (such as the proapoptotic protein BAD or the activated protein kinase AMPK). By interfering with this molecular pathway, KIs may promote cardiac damage [53]. The inhibition of the KIT and RAF1 pathways leads to vascular stem cell damage and endothelial dysfunction [54]. Endothelial cell apoptosis and exposure of subendothelial collagen initiate the coagulation process. Thus, on the one hand, endothelial dysfunction activates the coagulation process, leading to thromboembolic episodes, and, on the other hand, it destabilizes the atherosclerotic plaque, leading to ischemic episodes. In addition, a genetic predisposition in the form of 
RAF1 deletion leads to increased myocyte apoptosis, worse contractility, and enhanced left ventricular fibrosis and dilatation. The inhibition of the kinase pathway by KIs is associated with lower myocardial vascular density, which promotes cardiac fibrosis and reduces myocardial contractility [55]. These disorders are also initiated by induced arterial hypertension [56].

The mechanism of fluid retention caused by imatinib remains unclear. The blockage of PDGFR signaling that is responsible for the homeostasis of interstitial fluid was suggested as one of the mechanisms [57].

The molecular mechanisms underlying KI-induced cardiotoxicity are complex and not fully understood (e.g., an unclear mechanism of hypertension caused by copanlisib [38] or qTc prolongation due to inhibition of CDK4/6 [43]). On the one hand, various KIs can induce comparable cardiotoxic effects via similar mechanisms (e.g., promoting hypertension through the inhibition of NO formation by sorafenib or ibrutinib $[29,34])$. On the other hand, one KI can promote specific cardiotoxicity by way of a few molecular mechanisms (e.g., activation of numerous mechanisms leading to hypertension induced by TKIs [34]).

\section{Cardiotoxicity of Protein Kinase Inhibitors}

Protein KIs can lead to numerous cardiovascular toxicities including, but not limited to, hypertension, arrhythmias, cardiomyopathy or heart failure, fluid retention, thromboembolic events, and myocardial ischemia or infarction [40-46,53,54,57,58]. Considering the toxicity profile of KIs, the National Cancer Institute recommends that before starting therapy, each patient should be assessed for cardiovascular risk factors such as previous cardiovascular disease, blood pressure above 160/100 $\mathrm{mmHg}$, diabetes, dyslipidemia, smoking, obesity (body mass index $>30 \mathrm{~kg} / \mathrm{m}^{2}$ ), lack of physical activity, alcohol abuse, excessive salt consumption, and family history of cardiovascular disease [7,58]. Standard assessment of cardiac function is performed with ECG. In some patients, echocardiography with LVEF assessment and intima-media complex measurement by carotid ultrasound are used [58-60].

\subsection{Hypertension}

Sunitinib, sorafenib, lenvatinib, axitinib, pazopanib, and cabozantinib are KIs used in the treatment of renal cell carcinoma (RCC) $[34,61]$. In clinical trials, all these drugs were associated with hypertension [34,62]. A trial investigating the use of adjuvant sunitinib in patients with RCC showed hypertension in $44.7 \%$ of patients vs. $13.1 \%$ in the placebo group [63]. In a phase III clinical trial on metastatic RCC (mRCC), 17\% of the 903 participants receiving sorafenib developed hypertension, as compared to $1 \%$ in the placebo group [64]. A comparison of lenvatinib alone, everolimus alone, and a combination of the two agents in a phase II clinical trial on mRCC revealed that lenvantinib induces hypertension both when used alone and when used in combination (48\% vs. $41 \%$ vs. $10 \%$, respectively). In a phase II trial comparing axitinib and sorafenib, axitinib showed a higher toxicity profile, with $40 \%$ of patients showing any grade of hypertension (vs. $29 \%$ in the sorafenib group). However, this adverse event led to treatment discontinuation in only one patient in the axitinib group [45].

In a phase II clinical trial including patients with non-small cell lung cancer (NSCLC) and ALK rearrangement, brigatinib resulted in elevated blood pressure in $20 \%$ of the participants [65].

Ibrutinib is a BTK inhibitor used in hematologic B-cell malignancies. A large observational study of ibrutinib-treated patients estimated the risk of hypertension at around $2 \%$. The incidence of hypertension was higher in a clinical trial including 562 patients. It was reported in almost $80 \%$ of participants, of whom $18 \%$ developed grade hypertension according to the Common Terminology Criteria for Adverse Events (CTCAE), defined as a blood pressure $>160 / 100 \mathrm{mmHg}[66,67]$. There are scarce data on hypertension in patients treated with zanubrutinib, a drug approved for use in patients with refractory mantle cell lymphoma. It seems that zanubrutinib has a lower risk of elevated blood pressure than 
ibrutinib, with the rate of grade 3 hypertension reported at around 5\% in a pooled safety analysis of six studies and of almost $12 \%$ (when evaluated as adverse events of special interest) in another pooled analysis of two studies on refractory mantle cell lymphoma [68].

Another KI, selpercatinib, caused grade 3 or 4 hypertension in $21 \%$ of patients enrolled in phase I-II trial of thyroid cancer [69]. Similarly, in a population with NSCLC positive for rearranged during transfection (RET)-fusion, selpercatinib induced grade 3 or 4 hypertension in $14 \%$ of patients [70].

Other KI families associated with increased blood pressure include PI3K inhibitors and JAK inhibitors. An interesting example of PI3K inhibitors is copanlisib, a pan-class I PI3K inhibitor that caused hypertension of any grade in $54.8 \%$ of patients enrolled in a phase II clinical trial, and grade 3 in $40.5 \%$ of patients, usually within the first $2 \mathrm{~h}$ after the first infusion [32,71]. In contrast, one of the JAK inhibitors, ruxolitinib, resulted in increased systolic blood pressure after approximately 72 weeks of treatment [32,72].

Elevated blood pressure is observed most often in the first weeks of treatment [73]. Management strategies for TKI-induced hypertension according to CTCAE grades are presented in Table $3[7,58]$.

Table 3. Management strategy for TKI-induced hypertension according to the CTCAE grading system $[7,58]$.

\begin{tabular}{cc}
\hline Arterial Hypertension (Grade) & Action \\
\hline Grade 1 & Antihypertensive treatment \\
$140-149 / 90-99 \mathrm{mmHg}$ & Continuation of TKI therapy \\
\hline Grade 2 & Antihypertensive treatment modifications \\
$160-179 / 100-109 \mathrm{mmHg}$ & Continuation of TKI therapy \\
\hline Grade 3 & $\begin{array}{c}\text { Aggressive antihypertensive treatment } \\
\text { Discontinuation of TKI therapy }\end{array}$ \\
\hline $180 / \geq 110 \mathrm{mmHg}$ & D
\end{tabular}

Hypertension that occurs in patients treated with TKIs (e.g., sunitinib or sorafenib) is a predictor of treatment responses. Studies indicate that patients who develop hypertension during TKI therapy have a longer median overall survival and progression-free survival compared with those who do not develop this type of cardiotoxicity $[46,74,75]$. The latter group requires adequate and effective cardiovascular therapy.

\subsection{Arrhythmias}

\subsubsection{Bradycardia}

Oral inhibitors of ALK-positive tumors (e.g., crizotinib and ceritinib) were reported to cause sinus bradycardia. Trials on crizotinib treatment of NSCLC revealed a bradycardia frequency between $0.5 \%$ and $70 \%$, with the average time to the lowest heart rate after 18.6 weeks $[76,77]$. However, the reported incidence of this adverse event depends on the definition of bradycardia. In most cases, it is defined as asymptomatic and not related to other arrhythmias [76]. A meta-analysis suggested that the new generation of ALK inhibitors such as alectinib, brigatinib, or lorlatinib was associated with a similar risk of bradycardia when compared with crizotinib (estimated at around $8 \%$ ), while the risk was lower during the ceritinib treatment [78]. Therefore, it is suggested that these drugs should be avoided in patients with preexisting bradycardia and patients who use betablockers or other antiarrhythmic medications. The guidelines recommend regular heart rate monitoring with appropriate dose adjustments [79].

\subsubsection{QTc Prolongation}

Sunitinib and other KIs used in the treatment of mRCC have been reported to prolong QTc, an effect that seems to be dose-dependent. KIs used in this setting can also cause other conduction disturbances that lead to ECG abnormalities [53,80,81]. A meta-analysis that included 6548 patients from 18 clinical trials showed a significant risk of QTc prolongation for sunitinib but not for pazopanib or axitinib and sorafenib [80,82]. 
Selpercatinib (used in RET-fusion positive medullary thyroid cancer and NSCLC) was also shown to prolong QTc, with the reported rates of $6 \%$ for prolongation $>500 \mathrm{~ms}$ and $15 \%$ for prolongation $\geq 60 \mathrm{~ms}$ from baseline. In a phase I-II clinical trial on NSCLC, selpercatinib prolonged QTc in 10\% of participants [70]. Another RET inhibitor that prolongs QTC and causes torsade de pointes is vandetanib. A meta-analysis of phase II and III clinical trials revealed QTc prolongation (all grades) in 16.4\% of patients. In patients with thyroid cancer, who required longer treatment, the incidence increased to 18\% [83-85]. Another agent in this class is lenvatinib with QTc prolongation (any grade) reported in 9\% of participants (vs. $2 \%$ in the placebo group) and grade $\geq 3$ in $2 \%$ of participants (vs. $0 \%$ in the placebo group).

In the case of KIs used in the treatment of ALK-positive NSCLC, crizotinib and ceritinib, the risk of QTc prolongation does not appear to exceed 1-3\% of the treated population $[85,86]$.

It was suggested that EGFR inhibitors, including osimertinib and mobocertinib, also affect QTc, especially in patients with underlying conditions predisposing to QTc prolongation. A pooled safety analysis including 250 patients showed QTc prolongation of $>500 \mathrm{~ms}$ from baseline in $1.2 \%$ of patients and $>60 \mathrm{~ms}$ from baseline in $11 \%$. Cases of torsades de pointes were also associated with this treatment [87].

Additionally, BRAF inhibitors, such as vemurafenib and encorafenib, were shown to prolong the QTc interval. In a recent meta-analysis that included five trials of patients with metastatic melanoma, the proportion of patients experiencing QTc prolongation was not higher than when a MEK inhibitor was added to monotherapy with BRAF inhibitors [40].

Another class of drugs includes CDK4/6 inhibitors such as ribociclib, abemaciclib, and palbociclib. In a large meta-analysis of 6 clinical trials with a total of 3743 patients, palbociclib showed a significantly lower risk of QTc prolongation than ribociclib [88]. For ribociclib, the prolongation occurred during the first treatment cycle [89]. The combination of ribociclib with letrozole seems to be associated with a lower incidence of QTc prolongation than its combination with tamoxifen, as shown in the MONALEESA-7 trial (16\% vs. 7\%, respectively) [90].

Finally, among the KIs used for the treatment of Philadelphia chromosome-positive chronic myelogenous leukemia, bosutinib, dasatinib, and nilotinib are associated with QTc prolongation [91,92].

Considering these cardiotoxic effects, the above KIs should be administered with caution. Regular ECG monitoring with QTc interval measurement is recommended at baseline and during treatment. Additionally, thyroid hormones and electrolytes, including potassium, magnesium, and calcium, should be monitored regularly and corrected in the case of abnormalities. There are several formulas used for QTc interval calculations, including the Bazett, Fridericia, and Framingham calculators [91,93-95]. None of them have shown to be superior over the other. Any concomitant medications that could influence the QTc interval should be administered with caution. These include CYP3A4 inhibitors that increase KIs activity. Patients with preexisting conditions, including a history of QTC prolongation ( $>450 \mathrm{~ms}$ ), bradycardia, and hyperthyroidism, and with electrolyte disorders are also at higher risk for QTc prolongation. Any electrolyte abnormalities should be corrected, and the treatment should be interrupted if the QTC interval is greater than $500 \mathrm{~ms}[91,92,94-96]$.

\subsubsection{Other Arrhythmias}

Ibrutinib is a well-known agent that causes supraventricular and ventricular arrhythmias ( $7 \%$ and $0.5 \%$ of patients, respectively, as revealed by a safety report for 13,572 patients). In another series of more than 500 patients, the incidence of atrial fibrillation was 13\% [67]. The risk of atrial flutter and atrial fibrillation associated with zanubrutinib treatment appears to be lower (2\% in clinical trials) [68]. Conduction disturbances, rhythm abnormalities, and variations in the QRS amplitude or QRS axis are quite common ECG findings in patients receiving various KIs [33,91,92,94-96]. 


\subsection{Cardiomyopathy and Heart Failure}

Cardiomyopathy leading to heart failure is a serious adverse effect of treatment with various classes of KIs, including BCR-ABL kinase (e.g., dasatinib, imatinib), c-KIT (ripretinib, imatinib), BRAF/MEK, EGFR, and ALK inhibitors, as well as multitarget KIs used for $\mathrm{mRCC}$ treatment. It was reported that $1.6 \%$ of patients receiving dasatinib develop serious cardiac toxicity, including cardiomyopathy and heart failure [97,98].

For imatinib, the risk was reported to be $1-2 \%$ for clinically significant heart failure in patients with hematologic malignancies. On the other hand, the risk was not significant in patients with GIST, although elevated serum levels of brain natriuretic peptide in those patients suggest subclinical changes [35,97-102]. In a phase III clinical trial, ripretinib caused LVEF reduction in $2.6 \%$ of patients and heart failure in $1.2 \%$. In a pooled safety analysis of over 350 patients, the risk of heart failure was 1.7\% (for any grade, including also cases of diastolic dysfunction and ventricular hypertrophy) $[103,104]$.

BRAF inhibitors are associated with a higher risk of cardiomyopathy when combined with MEK inhibitors. During trametinib treatment for metastatic melanoma, $11 \%$ of patients were shown to develop left ventricular dysfunction. In a phase III trial, reduced LVEF occurred in $5.2 \%$ of patients. In these patients, cardiomyopathy resolved in most cases, allowing treatment continuation $[105,106]$.

Osimertinib, an EGFR TKI, was reported to reduce LVEF in about 3-5\% of patients in clinical trials and a pooled analysis. Most of these patients were found to be asymptomatic and did not require discontinuation of treatment. For mobocertinib, the risk seems to be similar, with a frequency of heart failure in a pooled safety analysis of 250 patients estimated at 2.7\% [107-109].

Sorafenib, sunitinib, pazopanib, axitinib, and lenvatinib are multitarget KIs used in $\mathrm{mRCC}$ and other malignancies. These drugs are also associated with the risk of heart failure. In a large meta-analysis of numerous KIs directed against VEGFR, heart failure was reported in $2.4 \%$ of patients vs. $0.8 \%$ of the placebo group [82]. Another meta-analysis of almost 7000 patients receiving sunitinib showed a $4.1 \%$ incidence of heart failure of any grade [110]. However, data from clinical trials and retrospective studies revealed a decrease in LVEF in $21-28 \%$ of patients, with a heart failure incidence of 3-15\% [110-112]. In patients with soft tissue sarcomas, pazopanib showed a significant decrease in LVEF compared with placebo (6.7\% vs. $2.4 \%$, respectively) [113]. Similar rates were observed for lenvatinib in patients with advanced thyroid cancer $[114,115]$.

The HER2 inhibitor lapatinib is used in metastatic breast cancer. Although its cardiac toxicity has not been studied as extensively as that of the anti-HER2 monoclonal antibody trastuzumab, a meta-analysis including 26 studies revealed left ventricular dysfunction in $1.6 \%$ of patients and LVEF reduction in $2.2 \%$ [116].

For the majority of the above inhibitors, regular echocardiographic evaluation of LVEF at baseline and during treatment is recommended. The risk of LVEF decline and heart failure is believed to be underestimated in clinical trials. However, in the case of inhibitors with lower or unclear risk (e.g., imatinib), monitoring is required only in patients with predisposing conditions or symptoms suggesting cardiac disease. Initiation of treatment in patients with LVEF $<50 \%$ should be avoided, and discontinuation of treatment is necessary in case of LVEF reduction [10,117-119].

\subsection{Fluid Retention}

Some KIs can cause fluid retention, leading to pulmonary edema or pericardial effusion. This symptom is observed during imatinib or bosutinib treatment, but it rarely leads to heart failure, according to existing data (about $1 \%$ of patients). Practical guidelines published in 2018 recommend standard treatment with diuretics and supportive care with dose reduction or discontinuation of treatment if needed $[32,120,121]$. Fluid retention with pulmonary edema was described also for dasatinib use [32,122]. Other drug classes associated with fluid retention are BCR-ABL inhibitors, while the FLT3 inhibitor gilteritinib was reported to cause edema of any grade in $24 \%$ of patients [32,123]. 
Patients with fluid retention should be assessed for cardiac, liver, kidney, and thyroid function, as well as serum protein and albumin levels. Moreover, ultrasound is recommended to diagnose and monitor patients suspected of pulmonary edema, pericardial effusion, ascites, and pleural effusion [57,122].

\subsection{Arterial Thromboembolic Events}

A large systematic review with a meta-analysis of 10,000 patients included in 10 phase II and III studies on sunitinib and sorafenib revealed a prevalence of arterial thromboembolic events of $1.4 \%$, with no difference between the drugs [124]. These events can also be attributed to other multitarget KIs used in $\mathrm{mRCC}$, as revealed by clinical trials for pazopanib (3\% of patients vs. $0 \%$ in the placebo group) and for lenvatinib (5\% of patients vs. $2 \%$ in the placebo group) [125-127].

Existing guidelines underline the importance of prevention and prompt identification and treatment of patients. Predisposing factors should be managed before the initiation of therapy. In the case of a thromboembolic event, treatment should be discontinued, and the condition should be treated according to applicable guidelines [128-130]. Any decision on treatment continuation must be considered on an individual basis.

\subsection{Venous Thromboembolic Events}

None of the two recent meta-analyses confirmed an elevated risk of venous thromboembolic events in patients treated with sunitinib, sorafenib, axitinib, pazopanib, and vandetanib $[126,131]$. The administration of anticoagulant prophylaxis during the antiangiogenic KI therapy in ambulatory patients in the absence of other risk factors for venous thromboembolic events is not recommended.

\subsection{Myocardial Ischemia and Infarction}

Some KIs are suspected to increase the risk of cardiac ischemia. For regorafenib, the incidence of cardiac ischemia in patients with metastatic colorectal cancer was $1.2 \%$ (vs. $0.4 \%$ in the placebo group) [132]. Another study reported an association with type 5 myocardial infarction [132,133]. For sorafenib, the incidence of cardiac ischemia was estimated at $2.9 \%$ (vs. 0.4 in the placebo group) and $2.7 \%$ (vs. $1.3 \%$ in the placebo group) $[91,134]$. Finally, ibrutinib use was associated with an incidence of cardiac ischemia of $1.4 \%$ in a study with over 500 patients with B-cell malignancies [67]. The importance of monitoring cardiac enzymes and ECG abnormalities remains uncertain [102].

Patients with coronary artery disease should be identified before initiation of therapy. The algorithm used to diagnose coronary artery disease in patients with cancer treated with KIs does not differ from that used in patients without cancer [135].

\section{Conclusions}

According to the literature, KIs therapy is associated with the risk of cardiotoxicity. Clinical trials reported that cardiotoxicity manifests itself as hypertension, heart failure, cardiac arrhythmias (bradyarrhythmias, tachyarrhythmias, qTc prolongation), thromboembolic events, fluid retention, and exacerbation of coronary artery disease.

Importantly, the assessment of cardiac dysfunction and cardiac adverse events was not the primary or secondary endpoint in any of the later-phase clinical trials described in Section 5; these outcomes were assessed retrospectively. The discrepancies in the reported frequency of cardiovascular complications may be due to differences in the definition of the same phenomenon across individual studies or the actual differences in the frequency and severity of these cardiac complications. Only studies specifically aimed at assessing cardiac dysfunction could provide comprehensive and sufficient data to develop clinical guidelines for the prevention and management of KI-induced cardiotoxicity.

The predictors and mechanisms of cardiotoxicity are yet to be defined in future research. The current gaps in knowledge result from the relative novelty of this specific drug class. The number of preclinical studies exploring the molecular mechanisms of KI 
activity and toxicity has been growing rapidly, providing more data but also some more questions. KIs are often multitargeted drugs, with new targets being commonly identified after the drug has been introduced to the market [136]. This multifunctionality poses a challenge in terms of developing a comprehensive classification system for these drugs [13].

Clearly, cardiotoxicity induced by KIs is affected by classic cardiovascular risk factors. Therefore, these risk factors should always be evaluated before initiation of therapy and managed accordingly. Cancer patients treated with KIs should undergo regular cardiac monitoring, including echocardiography, electrocardiography, and, in some patients, biochemical tests. Understanding the mechanisms and predictors of cardiotoxicity resulting from systemic anticancer treatment may allow adequate prevention of cardiovascular complications as well as a reduction in their incidence [137].

Author Contributions: Conceptualization, A.G.-W. and M.P.; writing-review and editing, A.G.-W., M.P., R.P.-M., M.K. and A.A. All authors have read and agreed to the published version of the manuscript.

Funding: This research received no external funding.

Institutional Review Board Statement: Not applicable.

Informed Consent Statement: Not applicable.

Data Availability Statement: Not applicable.

Acknowledgments: We thank Wioletta Korman for reviewing the manuscript, and Joanna Niemiec, for being our inspiration for creating the figures. Joanna Niemiec has passed last year. She stays our inspiration in numerous fields including exploring molecular pathways in cancer development and treatment.

Conflicts of Interest: The authors declare no conflict of interest.

\section{Abbreviations}

AKT Ak strain transforming protein kinase

ALL Acute lymphoblastic leukemia

ALK Anaplastic lymphoma kinase

AML Acute myeloid leukemia

ATP Adenosine triphosphate

BCR-ABL Breakpoint cluster region-Abelson proto-oncogene

BLNK B-cell linker protein

BRAF V-raf murine sarcoma viral oncogene homolog B

BTK Bruton tyrosine kinase

CDK 4/6 Cyclin-dependent kinases 4 and 6

CLL Chronic lymphocytic leukemia

CML Chronic myelogeneus leukemia

CSF-1R Colony stimulating factor receptor

DDR Discoidin domain receptor

EGFR Epidermal growth factor receptor

ER Endoplasmic reticulum

ERK Extracellular-signal-regulated kinases

ET-1 Endothelin-1

E2F E2 factor

FGFR Fibroblast growth factor receptors

FLT3 Fms-like tyrosine kinase-3

GAP GTPase-activating protein

GIST Gastrointestinal stromal tumor

HCC Hepatocellular carcinoma

HER2 Human epidermal growth factor receptor 2

HGFR Hepatocyte growth factor receptor 


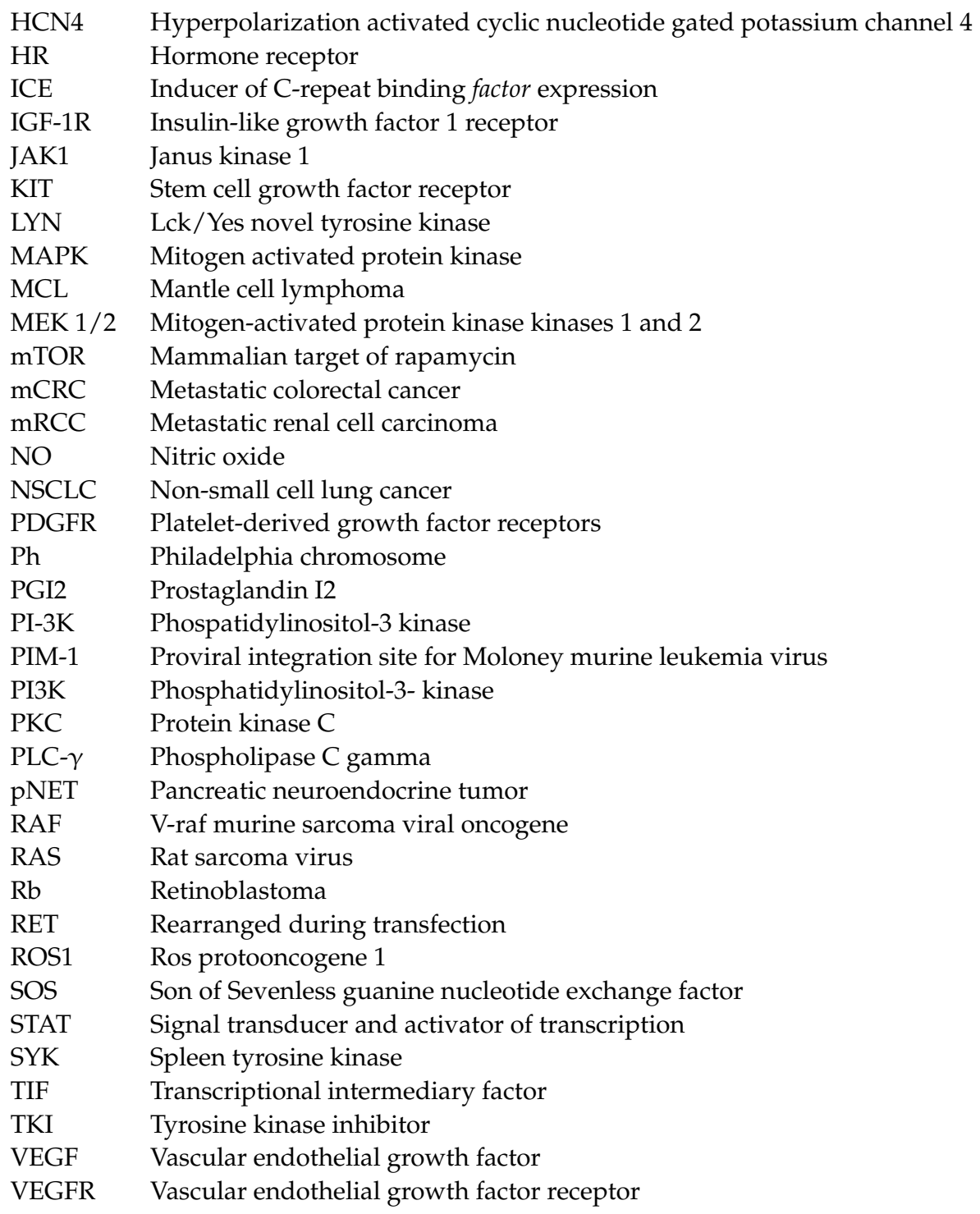

\section{References}

1. Ferlay, J.; Colombet, M.; Soerjomataram, I.; Mathers, C.; Parkin, D.M.; Piñeros, M.; Znaor, A.; Bray, F. Estimating the Global Cancer Incidence and Mortalityin 2018: GLOBOCAN Sources and Methods. Int. J. Cancer 2019, 144, 1941-1953. [CrossRef] [PubMed]

2. Bray, F.; Ferlay, J.; Soerjomataram, I.; Siegel, R.L.; Torre, L.A.; Jemal, A. Global Cancer Statistics 2018: GLOBOCAN Estimates of Incidence and Mortality Worldwide for 36 Cancers in 185 Countries. CA Cancer J. Clin. 2018, 68, 394-424. [CrossRef]

3. Singh, G.K.; Jemal, A. Socioeconomic and Racial/Ethnic Disparities in Cancer Mortality, Incidence, and Survival in the United States, 1950-2014: Over Six Decades of Changing Patterns and Widening Inequalities. J. Environ. Public Health 2017, $2017,2819372$. [CrossRef]

4. Hiatt, R.A.; Beyeler, N. Cancer and Climate Change. Lancet Oncol. 2020, 21, e519-e527. [CrossRef]

5. Esteban-Villarrubia, J.; Soto-Castillo, J.J.; Pozas, J.; Román-Gil, M.S.; Orejana-Martín, I.; Torres-Jiménez, J.; Carrato, A.; AlonsoGordoa, T.; Molina-Cerrillo, J. Tyrosine Kinase Receptors in Oncology. Int. J. Mol. Sci. 2020, 21, 8529. [CrossRef] [PubMed]

6. Dar, A.C.; Shokat, K.M. The Evolution of Protein Kinase Inhibitors from Antagonists to Agonists of Cellular Signaling. Annu. Rev. Biochem. 2011, 80, 769-795. [CrossRef]

7. Suter, T.M.; Ewer, M.S. Cancer Drugs and the Heart: Importance and Management. Eur. Heart J. 2013, 34, 1102-1111. [CrossRef]

8. Gonciar, D.; Mocan, L.; Zlibut, A.; Mocan, T.; Agoston-Coldea, L. Cardiotoxicity in HER2-Positive Breast Cancer Patients. Heart Fail. Rev. 2021, 26, 919-935. [CrossRef]

9. Bhagat, A.; Kleinerman, E.S. Anthracycline-Induced Cardiotoxicity: Causes, Mechanisms, and Prevention. Adv. Exp. Med. Biol. 2020, 1257, 181-192. [CrossRef]

10. Stone, J.R.; Kanneganti, R.; Abbasi, M.; Akhtari, M. Monitoring for Chemotherapy-Related Cardiotoxicity in the Form of Left Ventricular Systolic Dysfunction: A Review of Current Recommendations. JCO Oncol. Pract. 2021, 17, 228-236. [CrossRef]

11. Gavrin, L.K.; Saiah, E. Approaches to Discover Non-ATP Site Kinase Inhibitors. MedChemComm 2013, 4, 41-51. [CrossRef] 
12. Lamba, V.; Ghosh, I. New Directions in Targeting Protein Kinases: Focusing Upon True Allosteric and Bivalent Inhibitors. Curr. Pharm. Des. 2012, 18, 2936-2945. [CrossRef] [PubMed]

13. Roskoski, R. Classification of Small Molecule Protein Kinase Inhibitors Based upon the Structures of Their Drug-Enzyme Complexes. Pharmacol. Res. 2016, 103, 26-48. [CrossRef] [PubMed]

14. Sanchez, J.N.; Wang, T.; Cohen, M.S. BRAF and MEK Inhibitors: Use and Resistance in BRAF-Mutated Cancers. Drugs 2018, 78 , 549-566. [CrossRef] [PubMed]

15. García-Valverde, A.; Rosell, J.; Serna, G.; Valverde, C.; Carles, J.; Nuciforo, P.; Fletcher, J.A.; Arribas, J.; Politz, O.; Serrano, C. Preclinical Activity of PI3K Inhibitor Copanlisib in Gastrointestinal Stromal Tumor. Mol. Cancer Ther. 2020, 19, $1289-1297$. [CrossRef] [PubMed]

16. Reita, D.; Pabst, L.; Pencreach, E.; Guérin, E.; Dano, L.; Rimelen, V.; Voegeli, A.C.; Vallat, L.; Mascaux, C.; Beau-Faller, M. Molecular Mechanism of Egfr-Tki Resistance in Egfr-Mutated Non-Small Cell Lung Cancer: Application to Biological Diagnostic and Monitoring. Cancers 2021, 13, 4926. [CrossRef]

17. Chaar, M.; Kamta, J.; Ait-Oudhia, S. Mechanisms, Monitoring, and Management of Tyrosine Kinase Inhibitors-Associated Cardiovascular Toxicities. OncoTargets Ther. 2018, 11, 6227-6237. [CrossRef]

18. Li, W.; Feng, C.; Di, W.; Hong, S.; Chen, H.; Ejaz, M.; Yang, Y.; Xu, T.R. Clinical Use of Vascular Endothelial Growth Factor Receptor Inhibitors for the Treatment of Renal Cell Carcinoma. Eur. J. Med. Chem. 2020, 200, 2. [CrossRef]

19. Babaei, M.A.; Kamalidehghan, B.; Saleem, M.; Huri, H.Z.; Ahmadipour, F. Receptor Tyrosine Kinase (c-Kit) Inhibitors: A Potential Therapeutic Target in Cancer Cells. Drug Des. Dev. Ther. 2016, 10, 2443-2459. [CrossRef]

20. Thein, K.Z.; Velcheti, V.; Mooers, B.H.M.; Wu, J.; Subbiah, V. Precision Therapy for RET-Altered Cancers with RET Inhibitors Trends Cancer 2021, 7, 1074-1088. [CrossRef]

21. Holla, V.R.; Elamin, Y.Y.; Bailey, A.M.; Johnson, A.M.; Litzenburger, B.C.; Khotskaya, Y.B.; Sanchez, N.S.; Zeng, J.; Shufean, M.A.; Shaw, K.R.; et al. ALK: A Tyrosine Kinase Target for Cancer Therapy. Mol. Case Stud. 2017, 3, a001115. [CrossRef] [PubMed]

22. Chavez, J.C.; Sahakian, E.; Pinilla-Ibarz, J. Ibrutinib: An Evidence-Based Review of Its Potential in the Treatment of Advanced Chronic Lymphocytic Leukemia. Core Evid. 2013, 8, 37-45. [CrossRef] [PubMed]

23. Scheiblecker, L.; Kollmann, K.; Sexl, V. Cdk4/6 andMapk-Crosstalkas Opportunity for Cancer Treatment. Pharmaceuticals 2020, 13, 418. [CrossRef] [PubMed]

24. Kennedy, V.E.; Smith, C.C. FLT3Mutationsin Acute Myeloid Leukemia: Key Concepts and Emerging Controversies. Front. Oncol. 2020, 10, 2974. [CrossRef]

25. Hahn, V.S.; Lenihan, D.J.; Ky, B. Cancer Therapy-Induced Cardiotoxicity: Basic Mechanisms and Potential Cardioprotective Therapies. J. Am. Hear. Assoc. 2014, 3, e000665. [CrossRef]

26. Kong, C.-Y.; Guo, Z.; Song, P.; Zhang, X.; Yuan, Y.-P.; Teng, T.; Yan, L.; Tang, Q.-Z. Underlying the Mechanisms of DoxorubicinInduced Acute Cardiotoxicity: Oxidative Stress and Cell Death. Int. J. Biol. Sci. 2021, 18, 760-770. [CrossRef]

27. Shaikh, A.Y.; Shih, J.A. Chemotherapy-Induced Cardiotoxicity. Curr. Heart Fail. Rep. 2012, 9, 117-127. [CrossRef]

28. Perez, I.E.; Taveras Alam, S.; Hernandez, G.A.; Sancassani, R. Cancer Therapy-Related Cardiac Dysfunction: An Overviewfor the Clinician. Clin. Med. Insights Cardiol. 2019, 13, 1179546819866445. [CrossRef]

29. Allouchery, M.; Tomowiak, C.; Lombard, T.; Pérault-Pochat, M.C.; Salvo, F. Safety Pr ofile of Ibrutinib: An Analysis oftheWHOPharmacovigilance Database. Front. Pharmacol. 2021, 12, 5. [CrossRef]

30. Singh, A.P.; Glennon, M.S.; Umbarkar, P.; Gupte, M.; Galindo, C.L.; Zhang, Q.; Force, T.; Becker, J.R.; Lal, H. Ponatinib-Induced Cardiotoxicity: Delineatingthe Signalling Mechanisms and Potential Rescue Strategies. Cardiovasc. Res. 2019, 115, 966-977. [CrossRef]

31. Lamore, S.D.; Kohnken, R.A.; Peters, M.F.; Kolaja, K.L. Cardiovascular Toxicity Inducedby Kinase Inhibitors: Mechanisms and Preclinical Approaches. Chem. Res. Toxicol. 2020, 33, 125-136. [CrossRef] [PubMed]

32. Giudice, V.; Vecchione, C.; Selleri, C. Cardiotoxicity of Novel Targeted Hematological Therapies. Life 2020, 10, 344. [CrossRef] [PubMed]

33. Cheng, M.; Yang, F.; Liu, J.; Yang, D.; Zhang, S.; Yu, Y.; Jiang, S.; Dong, M. Tyrosine Kinase Inhibitors-Induced Arrhythmias: From Molecular Mechanisms, Pharmacokinetics to Therapeutic Strategies. Front. Cardiovasc. Med. 2021, 8, 75801. [CrossRef]

34. Møller, N.B.; Budolfsen, C.; Grimm, D.; Krüger, M.; Infanger, M.; Wehland, M.; Magnusson, N.E. Drug-Induced Hypertension Caused by Multikinase Inhibitors (Sorafenib, Sunitinib, Lenvatinib and Axitinib) in Renal Cell Carcinoma Treatment. Int. J. Mol. Sci. 2019, 20, 4712. [CrossRef]

35. Kerkelä, R.; Grazette, L.; Yacobi, R.; Iliescu, C.; Patten, R.; Beahm, C.; Walters, B.; Shevtsov, S.; Pesant, S.; Clubb, F.J.; et al. Cardiotoxicity of the Cancer Therapeutic Agent Imatinib Mesylate. Nat. Med. 2006, 12, 908-916. [CrossRef]

36. Zhang, Z.; Huang, T.-Q.; Nepliouev, I.; Zhang, H.; Barnett, A.S.; Rosenberg, P.B.; Ou, S.-H.I.; Stiber, J.A. Crizotinib Inhibits Hyperpolarization-Activated Cyclic Nucleotide-Gated Channel 4 Activity. Cardio-Oncology 2017, 3, 471. [CrossRef] [PubMed]

37. Wu, J.; Liu, C.; Tsui, S.T.; Liu, D. Second-Generation Inhibitors of Bruton Tyrosine Kinase. J. Hematol. Oncol. 2016, 9, 80. [CrossRef]

38. Lenz, G.; Hawkes, E.; Verhoef, G.; Haioun, C.; Thye Lim, S.; SeogHeo, D.; Ardeshna, K.; Chong, G.; Haaber, J.; Shi, W.; et al. SingleAgent Activity of Phosphatidylinositol3-Kinase Inhibition with Copanlisib in Patients with Molecularly Defined Relapsedor Refractory Diffuse Large B-Cell Lymphoma. Leukemia 2020, 34, 2184-2197. [CrossRef]

39. Northcott, C.A.; Poy, M.N.; Najjar, S.M.; Watts, S.W. Phosphoinositide3-Kinase Mediates Enhanced Spontaneous and AgonistInduced Contraction in Aorta of Deoxycorticosterone Acetate-Salt Hypertensive Rats. Circ. Res. 2002, 91, 360-369. [CrossRef] 
40. Mincu, R.I.; Mahabadi, A.A.; Michel, L.; Mrotzek, S.M.; Schadendorf, D.; Rassaf, T.; Totzeck, M. Cardiovascular Adverse Events Associated with BRAF and MEK Inhibitors: A Systematic Review and Meta-Analysis. JAMA Netw. Open 2019, 2, e198890. [CrossRef]

41. Arangalage, D.; Degrauwe, N.; Michielin, O.; Monney, P.; Özdemir, B.C. Pathophysiology, Diagnosis and Management of Cardiac Toxicity Induced by Immune Checkpoint Inhibitors and BRAF and MEK Inhibitors. Cancer Treat. Rev. 2021, 100, 10228. [CrossRef] [PubMed]

42. Banks, M.; Crowell, K.; Proctor, A.; Jensen, B.C. Cardiovascular Effects of the MEK Inhibitor, Trametinib: A Case Report, Literature Review, and Consideration of Mechanism. Cardiovasc. Toxicol. 2017, 17, 487-493. [CrossRef] [PubMed]

43. Shah, A.; Bloomquist, E.; Tang, S.; Fu, W.; Bi, Y.; Liu, Q.; Yu, J.; Zhao, P.; Palmby, T.R.; Goldberg, K.B.; et al. FDA Approval: Ribociclib for the Treatment of Postmenopausal Women with Hormone Receptor-Positive, HER2-Negative Advancedor Metastatic Breast Cancer. Clin. Cancer Res. 2018, 24, 2999-3004. [CrossRef] [PubMed]

44. Zhu, X.; Stergiopoulos, K.; Wu, S. Risk of Hypertension and Renal Dysfunction with an Angiogenesis Inhibitor Sunitinib: Systematic Review and Meta-Analysis. Acta Oncol. 2009, 48, 9-17. [CrossRef]

45. Rini, B.I.; Quinn, D.I.; Baum, M.; Wood, L.S.; Tarazi, J.; Rosbrook, B.; Arruda, L.S.; Cisar, L.; Roberts, W.G.; Kim, S.; et al Hypertension among Patients with Renal Cell Carcinoma Receiving Axitinibor Sorafenib: Analysis from the R and omized Phase III AXIS Trial. Target. Oncol. 2015, 10, 45-53. [CrossRef]

46. Chu, T.F.; Rupnick, M.A.; Kerkela, R.; Dallabrida, S.M.; Zurakowski, D.; Nguyen, L.; Morgan, J.A. Cardiotoxicity Associated with Tyrosine Kinase Inhibitor Sunitinib. Lancet 2007, 370, 2011-2019. [CrossRef]

47. Robinson, E.S.; Khankin, E.V.; Choueiri, T.K.; Dhawan, M.S.; Rogers, M.J.; Karumanchi, S.A.; Humphreys, B.D. Suppression of the Nitric Oxide Pathway in Metastatic Renal Cell Carcinoma Patients Receiving Vascular Endothelial Growth Factor-Signaling Inhibitors. Hypertension 2010, 56, 1131-1136. [CrossRef]

48. Mayer, E.L.; Dallabrida, S.M.; Rupnick, M.A.; Redline, W.M.; Hannagan, K.; Ismail, N.S.; Burstein, H.J.; Beckman, J.A. Contrary Effects of the Rtk Inhibitor Vandetanibon Constitutive and Flow-Stimulated Nitric Oxide Elaboration in Humans. Hypertension 2015, 58, 85-92. [CrossRef]

49. Veronese, M.L.; Mosenkis, A.; Flaherty, K.T.; Gallagher, M.; Stevenson, J.P.; Townsend, R.R.; O’Dwyer, P.J. Mechanisms of Hypertension Associated with BAY43-9006. J. Clin. Oncol. 2006, 24, 1363-1369. [CrossRef]

50. Shopp, G.M.; Helson, L.; Bouchard, A.; Salvail, D.; Majeed, M. Liposomes Ameliorate Crizotinib-and Nilotinib-Induced Inhibition of the Cardiac IKr Channel and QTc Prolongation. Anticancer Res. 2014, 34, 4733-4740.

51. Hsieh, P.C.H.; Davis, M.E.; Gannon, J.; Mac Gillivray, C.; Lee, R.T. Controlled Delivery of PDGF-BB for Myocardial Protection Using Injectable Self-Assembling Peptide Nanofibers. J. Clin. Investig. 2006, 116, 237-248. [CrossRef] [PubMed]

52. Liu, J.; Wu, L.L.; Li, L.; Zhang, L.; Song, Z.E. Growth-Promoting Effect of Platelet-Derived Growth Factor on Rat Cardiac Myocytes. Regul. Pept. 2005, 127, 11-18. [CrossRef] [PubMed]

53. Schmidinger, M.; Zielinski, C.C.; Vogl, U.M.; Bojic, A.; Bojic, M.; Schukro, C.; Ruhsam, M.; Hejna, M.; Schmidinger, H. Cardiac Toxicity of Sunitinib and Sorafenib in Patients with Metastatic Renal Cell Carcinoma. J. Clin. Oncol. 2008, 26, 5204-5212. [CrossRef] [PubMed]

54. Force, T.; Krause, D.S.; Van Etten, R.A. Molecular Mechanisms of Cardiotoxicity of Tyrosine Kinase Inhibition. Nat. Rev. Cancer 2007, 7, 332-344. [CrossRef] [PubMed]

55. Izumiya, Y.; Shiojima, I.; Sato, K.; Sawyer, D.B.; Colucci, W.S.; Walsh, K. Vascular Endothelial Growth Factor Blockade Promotes the Transition from Compensatory Cardiac Hypertrophy to Failure in Response to Pressure Overload. Hypertension 2006, 47, 887-893. [CrossRef]

56. Kamba, T.; Tam, B.Y.Y.; Hashizume, H.; Haskell, A.; Sennino, B.; Mancuso, M.R.; Norberg, S.M.; O'Brien, S.M.; Davis, R.B.; Gowen, L.C.; et al. VEGF-Dependent Plasticity of Fenestrated Capillaries in the Normal Adult Microvasculature. Am. J. Physiol. Heart Circ. Physiol. 2006, 290, 560-576. [CrossRef]

57. Kim, K.W.; Shinagare, A.B.; Krajewski, K.M.; Pyo, J.; Tirumani, S.H.; Jagannathan, J.P.; Ramaiya, N.H. Fluid Retention Associated with Imatinib Treatment in Patients with Gastrointestinal Stromal Tumor: Quantitative Radiologic Assessment and Implications for Management. Korean J. Radiol. 2015, 16, 304-313. [CrossRef]

58. De Jesus-Gonzalez, N.; Robinson, E.; Moslehi, J.; Humphreys, B.D. Management of Antiangiogenic Therapy-Induced Hypertension. Hypertension 2012, 60, 607-615. [CrossRef]

59. .Opolski, G.; Krzakowski, M.; Szmit, S.; Banach, J.; Chudzik, M.; Cygankiewicz, I.; Drozdz, J.; Filipiak, K.J.; Grabowski, M.; Kaczmarek, K.; et al. Recommendations of National Team of Cardiologic and Oncologic Supervision on Cardiologic Safety of Patients with Breast Cancer. The Prevention and Treatment of Cardiovascular Complications in Breast Cancer. The Task Force of National Consultants in Cardiology and Clinical Oncology for the Elaboration of Recommendations of Cardiologic Proceeding with Patients with Breast Cancer. Kardiol. Pol. 2011, 69, 520-530.

60. .Laurent, S.; Narkiewicz, K.; Ruilope, L.; Rynkiewicz, A.; Schmieder, R.E.; Struijker Boudier, H.A.; Zanchetti, A. 2007 ESH-ESC Guidelines for the Management of Arterial Hypertension: The Task Force for the Management of Arterial Hypertension of the European Society of Hypertension (ESH) and of the European Society of Cardiology (ESC). Blood Press. 2007, 16, 135-232. [CrossRef]

61. Hsieh, J.J.; Purdue, M.P.; Signoretti, S.; Swanton, C.; Albiges, L.; Schmidinger, M.; Heng, D.Y.; Larkin, J.; Ficarra, V. Renal Cell Carcinoma. Nat. Rev. Dis. Prim. 2017, 3, 17009. [CrossRef] 
62. Zhang, X.; Shao, Y.; Wang, K. Incidence and Risk of Hypertension Associated with Cabozantinib in Cancer Patients: A Systematic Review and Meta-Analysis. Expert Rev. Clin. Pharmacol. 2016, 9, 1109-1115. [CrossRef]

63. Ravaud, A.; Motzer, R.J.; Pandha, H.S.; George, D.J.; Pantuck, A.J.; Patel, A.; Chang, Y.-H.; Escudier, B.; Donskov, F.; Magheli, A.; et al. Adjuvant Sunitinib in High-Risk Renal-Cell Carcinoma after Nephrectomy. N. Engl. J. Med. 2016, 375, 2246-2254. [CrossRef] [PubMed]

64. Escudier, B.; Eisen, T.; Stadler, W.M.; Szczylik, C.; Oudard, S.; Staehler, M.; Negrier, S.; Chevreau, C.; Desai, A.A.; Rolland, F.; et al. Sorafenibfor Treatment of Renal Cell Carcinoma: Final Efficacy and Safety Results of the Phase III Treatment Approaches in Renal Cancer Global Evaluation Trial. J. Clin. Oncol. 2009, 27, 3312-3318. [CrossRef] [PubMed]

65. Kim, D.W.; Tiseo, M.; Ahn, M.J.; Reckamp, K.L.; Hansen, K.H.; Kim, S.W.; Huber, R.M.; West, H.L.; Groen, H.J.M.; Hochmair, M.J.; et al. Brigatinib in Patients with Crizotinib-Refractory Anaplastic Lymphoma Kinase-Positive Non-Small-Cell Lung Cancer: A Randomized, Multicenter Phase II Trial. J. Clin. Oncol. 2017, 35, 2490-2498. [CrossRef] [PubMed]

66. Salem, J.-E.; Manouchehri, A.; Bretagne, M.; Lebrun-Vignes, B.; Groarke, J.D.; Johnson, D.B.; Yang, T.; Reddy, N.M.; FunckBrentano, C.; Brown, J.R.; et al. Cardiovascular Toxicities Associated with Ibrutinib. J. Am. Coll. Cardiol. 2019, 74, 1667-1678. [CrossRef] [PubMed]

67. Dickerson, T.; Wiczer, T.; Waller, A.; Philippon, J.; Porter, K.; Haddad, D.; Guha, A.; Rogers, K.A.; Bhat, S.; Byrd, J.C.; et al. Hypertension and Incident Cardiovascular Events Following Ibrutinib Initiation. Blood 2019, 134, 1919-1928. [CrossRef]

68. Tam, C.S.; Dimopoulos, M.A.; Garcia-Sanz, R.; Trotman, J.; Opat, S.; Roberts, A.W.; Owen, R.G.; Song, Y.; Xu, W.; Zhu, J.; et al. Pooled Safety Analysis of Zanubrutinib Monotherapy in Patients with B-Cell Malignancies. Blood Adv. 2021, 6, 1296-1308. [CrossRef]

69. Wirth, L.J.; Sherman, E.; Robinson, B.; Solomon, B.; Kang, H.; Lorch, J.; Worden, F.; Brose, M.; Patel, J.; Leboulleux, S.; et al. Efficacy of Selpercatinibin RET-Altered Thyroid Cancers. N. Engl. J. Med. 2020, 383, 825-835. [CrossRef]

70. Drilon, A.; Oxnard, G.R.; Tan, D.S.W.; Loong, H.H.F.; Johnson, M.; Gainor, J.; Mc Coach, C.E.; Gautschi, O.; Besse, B.; Cho, B.C.; et al. Efficacy of Selpercatinibin RET Fusion-Positive Non-Small-Cell Lung Cancer. N. Engl. J. Med. 2020, 383, 813-824. [CrossRef]

71. Dreyling, M.; Morschhauser, F.; Bouabdallah, K.; Bron, D.; Cunningham, D.; Assouline, S.E.; Verhoef, G.; Linton, K.; Thieblemont, C.; Vitolo, U.; et al. Phase II Study of Copanlisib, a PI3K Inhibitor, in Relapsedor Refractory, Indolentor Aggressive Lymphoma. Ann. Oncol. 2017, 28, 2169-2178. [CrossRef] [PubMed]

72. Vannucchi, A.M.; Kiladjian, J.J.; Griesshammer, M.; Masszi, T.; Durrant, S.; Passamonti, F.; Harrison, C.N.; Pane, F.; Zachee, P.; Mesa, R.; et al. Ruxolitinib versus Standard Therapy for the Treatment of Polycythemia Vera. N. Engl. J. Med. 2015, 372, 426-435. [CrossRef]

73. Celletti, F.L.; Hilfiker, P.R.; Ghafouri, P.; Dake, M.D. Effect of Human Recombinant Vascular Endothelial Growth Factor 165 on Progression of Atherosclerotic Plaque. J. Am. Coll. Cardiol. 2001, 37, 2126-2130. [CrossRef]

74. Rini, B.I.; Schiller, J.H.; Fruehauf, J.P.; Cohen, E.E.W.; Tarazi, J.C.; Rosbrook, B.; Bair, A.H.; Ricart, A.D.; Olszanski, A.J.; Letrent, K.J.; et al. Diastolic Blood Pressure as a Biomarker of Axitinib Efficacy in Solid Tumors. Clin. Cancer Res. 2011, 17, 3841-3849. [CrossRef] [PubMed]

75. Szmit, S.; Langiewicz, P.; Łnierek, J.; Nurzyński, P.; Zaborowska, M.; Filipiak, K.J.; Opolski, G.; Szczylik, C. Hypertension as a Predictive Factor for Survival Outcomes in Patients with Metastatic Renal Cell Carcinoma Treated with Sunitinib after Progression on Cytokines. Kidney Blood Press. Res. 2012, 35, 18-25. [CrossRef] [PubMed]

76. Ou, S.H.I.; Tong, W.P.; Azada, M.; Siwak-Tapp, C.; Dy, J.; Stiber, J.A. Heart Rate Decrease during Crizotinib Treatment and Potential Correlation to Clinical Response. Cancer 2013, 119, 1969-1975. [CrossRef]

77. Ye, J.Z.; Hansen, F.B.; Mills, R.W.; Lundby, A. Oncotherapeutic Protein Kinase Inhibitors Associated with Pro-Arrhythmic Liability. JACC CardioOncol. 2021, 3, 88-97. [CrossRef]

78. Cirne, F.; Zhou, S.; Kappel, C.; El-Kadi, A.; Barron, C.C.; Ellis, P.M.; Sanger, S.; Leong, D.P. ALKInhibitor-Induced Bradycardia: A Systematic-Review and Meta-Analysis. Lung Cancer 2021, 161, 9-17. [CrossRef]

79. Summary of Product Characteristics-Xalkori. Available online: https://www.ema.europa.eu/en/documents/product-information/ xalkori-epar-product-information_en.pdf (accessed on 30 January 2022).

80. Shah, R.R.; Morganroth, J.; Shah, D.R. Cardiovascular Safety of Tyrosine Kinase Inhibitors: With a Special Focus on Cardiac Repolarisation (QT Interval). Drug Saf. 2013, 36, 295-316. [CrossRef]

81. Bello, C.L.; Mulay, M.; Huang, X.; Patyna, S.; Dinolfo, M.; Levine, S.; Van Vugt, A.; Toh, M.; Baum, C.; Rosen, L. Electrocardiographic Characterization of the QTc Intervalin Patients with Advanced Solid Tumors: Pharmacokinetic-Pharmacodynamic Evaluation of Sunitinib. Clin. Cancer Res. 2009, 15, 7045-7052. [CrossRef]

82. Ghatalia, P.; Je, Y.; Kaymakcalan, M.D.; Sonpavde, G.; Choueiri, T.K. QTc Interval Prolongation with Vascular Endothelial Growth Factor Receptor Tyrosine Kinase Inhibitors. Br. J. Cancer 2015, 112, 296-305. [CrossRef] [PubMed]

83. Zang, J.; Wu, S.; Tang, L.; Xu, X.; Bai, J.; Ding, C.; Chang, Y.; Yue, L.; Kang, E.; He, J. Incidence and Risk of QTc Interval Prolongation among Cancer Patients Treated with Vandetanib: A Systematic Review and Meta-Analysis. PLoS ONE 2012, 7, e30353. [CrossRef] [PubMed]

84. Roden, D.M. Predicting Drug-Induced QT Prolongation and Torsadesde Pointes. J. Physiol. 2016, 594, 2459-2468. [CrossRef]

85. Coppola, C.; Rienzo, A.; Piscopo, G.; Barbieri, A.; Arra, C.; Maurea, N. Management of QT Prolongation Induced by Anti-Cancer Drugs: Target Therapy and Old Agents. Different Algorithms for Different Drugs. Cancer Treat. Rev. 2018, 63, 135-143. [CrossRef] [PubMed] 
86. Muller, I.B.; De Langen, A.J.; Honeywell, R.J.; Giovannetti, E.; Peters, G.J. Overcoming Crizotinib Resistance in ALK-Rearranged NSCLC with the Second-Generation ALK-Inhibitor Ceritinib. Expert Rev. Anticancer. Ther. 2016, 16, 147-157. [CrossRef]

87. Schiefer, M.; Hendriks, L.E.L.; Dinh, T.; Lalji, U.; Dingemans, A.M.C. Current Perspective: Osimertinib-Induced QT Prolongation: New Drugs with New Side-Effects Need Careful Patient Monitoring. Eur. J. Cancer 2018, 91, 92-98. [CrossRef] [PubMed]

88. Petrelli, F.; Ghidini, A.; Pedersini, R.; Cabiddu, M.; Borgonovo, K.; Chiara Parati, M.; Ghilardi, M.; Amoroso, V.; Berruti, A.; Barni, S. Comparative Efficacy of Palbociclib, Ribociclib and Abemaciclib for ER+ Metastatic Breast Cancer: An Adjusted Indirect Analysis of Randomized Controlled Trials. Breast Cancer Res. Treat. 2019, 174, 597-604. [CrossRef] [PubMed]

89. LouwrensBraal, C.; Jongbloed, E.M.; Wilting, S.M.; Mathijssen, R.H.J.; Koolen, S.L.W.; Jager, A. Inhibiting CDK $4 / 6$ in Breast Cancer with Palbociclib, Ribociclib, and Abemaciclib: Similarities and Differences. Drugs 2021, 81, 317-331. [CrossRef]

90. Tripathy, D.; Im, S.-A.; Colleoni, M.; Franke, F.; Bardia, A.; Harbeck, N.; Hurvitz, S.A.; Chow, L.; Sohn, J.; Lee, K.S.; et al. Ribociclib plus Endocrine Therapy for Premenopausal Women with Hormone-Receptor-Positive, Advanced Breast Cancer (MONALEESA-7): A Randomised Phase 3 Trial. Lancet Oncol. 2018, 19, 904-915. [CrossRef]

91. Porta-Sánchez, A.; Gilbert, C.; Spears, D.; Amir, E.; Chan, J.; Nanthakumar, K.; Thavendiranathan, P. Incidence, Diagnosis, and Management of QT Prolongation Induced by Cancer Therapies: A Systematic Review. J. Am. Heart Assoc. 2017, 6, e007724. [CrossRef]

92. Strevel, E.L.; Ing, D.J.; Siu, L.L. Molecularly Targeted Oncology Therapeutics and Prolongation of the QT Interval. J. Clin. Oncol. 2007, 25, 3362-3371. [CrossRef] [PubMed]

93. 93. De Oliveira Neto, N.R.; De Oliveira, W.S.; Campos Pinto, G.D.; De Oliveira, E.S.R.; Da Silveira Barros, M.d.N.D. A Practical Method for QTc Interval Measurement. Cureus 2020, 12, e12122. [CrossRef]

94. Muluneh, B.; Richardson, D.R.; Hicks, C.; Jensen, B.C.; Zeidner, J.F. Trials and Tribulations of Corrected QT Interval Monitoring in Oncology: Rationale for a Practice-Changing Standardized Approach. J. Clin. Oncol. 2019, 37, 2719-2721. [CrossRef]

95. De Lemos, M.L.; Kung, C.; Kletas, V.; Badry, N.; Kang, I. Approach to Initiating QT-Prolonging Oncology Drugs in the Ambulatory Setting. J. Oncol. Pharm. Pract. 2019, 25, 198-204. [CrossRef] [PubMed]

96. AbuRmilah, A.A.; Lin, G.; Begna, K.H.; Friedman, P.A.; Herrmann, J. Risk of QTc Prolongation among Cancer Patients Treated with Tyrosine Kinase Inhibitors. Int. J. Cancer 2020, 147, 3160-3167. [CrossRef] [PubMed]

97. Moslehi, J.J.; Deininger, M. Tyrosine Kinase Inhibitor-Associated Cardiovascular Toxicity in Chronic Myeloid Leukemia. J. Clin. Oncol. 2015, 33, 4210-4218. [CrossRef]

98. Cirmi, S.; ElAbd, A.; Letinier, L.; Navarra, M.; Salvo, F. Cardiovascular Toxicity of Tyrosine Kinase Inhibitors Used in Chronic Myeloid Leukemia: An Analysis of the FDA Adverse Event Reporting System Database (FAERS). Cancers 2020, 12, 826. [CrossRef]

99. Fernández, A.; Sanguino, A.; Peng, Z.; Ozturk, E.; Chen, J.; Crespo, A.; Wulf, S.; Shavrin, A.; Qin, C.; Ma, J.; et al. An Anticancer C-Kit Kinase Inhibitor Is Reengineered to Make It More Active and Less Cardiotoxic. J. Clin. Investig. 2007, 117, 4044-4054. [CrossRef]

100. Trent, J.C.; Patel, S.S.; Zhang, J.; Araujo, D.M.; Plana, J.C.; Lenihan, D.J.; Fan, D.; Patel, S.R.; Benjamin, R.S.; Khakoo, A.Y. Rare Incidence of Congestive Heart Failure in Gastrointestinal Stromal Tumor and Other Sarcoma Patients Receiving Imatinib Mesylate. Cancer 2010, 116, 184-192. [CrossRef]

101. Estabragh, Z.R.; Knight, K.; Watmough, S.J.; Lane, S.; Vinjamuri, S.; Hart, G.; Clark, R.E. A Prospective Evaluation of Cardiac Function in Patients with Chronic Myeloid Leukaemia Treated with Imatinib. Leuk. Res. 2011, 35, 49-51. [CrossRef]

102. Perik, P.J.; Rikhof, B.; deJong, F.A.; Verweij, J.; Gietema, J.A.; van der Graaf, W.T.A. Results of Plasma N-Terminalpro B-Type Natriuretic Peptide and Cardiac Troponin Monitoring in GIST Patients Do Not Support the Existence of Imatinib-Induced Cardiotoxicity. Ann. Oncol. 2008, 19, 359-361. [CrossRef] [PubMed]

103. Blay, J.-Y.; Serrano, C.; Heinrich, M.C.; Zalcberg, J.; Bauer, S.; Gelderblom, H.; Schöffski, P.; Jones, R.L.; Attia, S.; D’Amato, G.; et al. Ripretinibin Patients with Advanced Gastrointestinal Stromal Tumours (INVICTUS): A Double-Blind, Randomised, Placebo-Controlled, Phase 3 Trial. Lancet Oncol. 2020, 21, 923-934. [CrossRef]

104. Von Mehren, M.; Serrano, C.; Bauer, S.; Gelderblom, H.; George, S.; Heinrich, M.; Schöffski, P.; Zalcberg, J.; Chi, P.; Jones, R.L.; et al INVICTUS: A Phase III, Interventional, Double-Blind, Placebo-Controlled Study to Assess the Safety and Efficacy of Ripretinibas $\geq 4$ th-Line Therapyin Patients with Advanced Gastrointestinal Stromal Tumors (GIST) Who Have Received Treatment with Prior Ant. Ann. Oncol. 2019, 30, v925-v926. [CrossRef]

105. Kim, K.B.; Kefford, R.; Pavlick, A.C.; Infante, J.R.; Ribas, A.; Sosman, J.A.; Fecher, L.A.; Millward, M.; Mc Arthur, G.A.; Hwu, P.; et al. Phase II Study of the MEK1/MEK2 Inhibitor Trametinibin Patients with Metastatic BRAF-Mutant Cutaneous Melanoma Previously Treated with or without a BRAF Inhibitor. J. Clin. Oncol. 2013, 31, 482-489. [CrossRef]

106. Flaherty, K.T.; Robert, C.; Hersey, P.; Nathan, P.; Garbe, C.; Milhem, M.; Demidov, L.V.; Hassel, J.C.; Rutkowski, P.; Mohr, P.; et al. Improved Survival with MEK Inhibition in BRAF-Mutated Melanoma. N. Engl. J. Med. 2012, 367, 107-114. [CrossRef]

107. Mok, T.S.; Wu, Y.-L.; Ahn, M.-J.; Garassino, M.C.; Kim, H.R.; Ramalingam, S.S.; Shepherd, F.A.; He, Y.; Akamatsu, H.; Theelen, W.S.M.E.; et al. Osimertinibor Platinum-Pemetrexed in EGFRT790 M-Positive Lung Cancer. N. Engl. J. Med. 2017, 376, 629-640. [CrossRef]

108. Ewer, M.S.; Tekumalla, S.H.; Walding, A.; Atuah, K.N. Cardiac Safety of Osimertinib: A Review of Data. J. Clin. Oncol. 2021, 39, 328-337. [CrossRef]

109. Mobocertinib Succinate. Am. J. Health Pharm. 2021, 79, 3-5. [CrossRef] 
110. Rock, E.P.; Goodman, V.; Jiang, J.X.; Mahjoob, K.; Verbois, S.L.; Morse, D.; Dagher, R.; Justice, R.; Pazdur, R. Food and Drug Administration Drug Approval Summary: Sunitinib Malate for the Treatment of Gastrointestinal Stromal Tumor and Advanced Renal Cell Carcinoma. Oncologist 2007, 12, 107-113. [CrossRef]

111. Ghatalia, P.; Morgan, C.J.; Je, Y.; Nguyen, P.L.; Trinh, Q.D.; Choueiri, T.K.; Sonpavde, G. Congestive Heart Failure with Vascular Endothelial Growth Factor Receptor Tyrosine Kinase Inhibitors. Crit. Rev. Oncol. Hematol. 2015, 94, 228-237. [CrossRef]

112. Motzer, R.J.; Hutson, T.E.; Tomczak, P.; Michaelson, M.D.; Bukowski, R.M.; Rixe, O.; Oudard, S.; Negrier, S.; Szczylik, C.; Kim, S.T.; et al. Sunitinib versus Interferon Alfa in Metastatic Renal-Cell Carcinoma. N. Engl. J. Med. 2007, 356, 115-124. [CrossRef] [PubMed]

113. Van Der Graaf, W.T.A.; Blay, J.Y.; Chawla, S.P.; Kim, D.W.; Bui-Nguyen, B.; Casali, P.G.; Schöffski, P.; Aglietta, M.; Staddon, A.P.; Beppu, Y.; et al. Pazopanib for Metastatic Soft-Tissue Sarcoma (PALETTE): A Randomised, Double-Blind, Placebo-Controlled Phase3 Trial. Lancet 2012, 379, 1879-1886. [CrossRef]

114. Marina, M.; Serra, M.F.; Del Rio, P.; Ceresini, G. Evaluation of the QTc Interval during Lenvatinib Treatment in RadioiodineRefractory Differentiated Thyroid Cancer: Reports from the Real-Life Clinical Practice. Future Oncol. 2019, 15, 7-12. [CrossRef] [PubMed]

115. Schlumberger, M.; Tahara, M.; Wirth, L.J.; Robinson, B.; Brose, M.S.; Elisei, R.; Habra, M.A.; Newbold, K.; Shah, M.H.; Hoff, A.O.; et al. Lenvatinib versus Placebo in Radioiodine-Refractory Thyroid Cancer. N. Engl. J. Med. 2015, 372, 621-630. [CrossRef] [PubMed]

116. Choi, H.D.; Chang, M.J. Cardiac Toxicities of Lapatinib in Patients with Breast Cancer and Other HER2-Positive Cancers: A Meta-Analysis. Breast Cancer Res. Treat. 2017, 166, 927-936. [CrossRef]

117. Habibian, M.; Lyon, A.R. Monitoring the Heart during Cancer Therapy. Eur. Heart J. 2019, 21, M44-M49. [CrossRef]

118. Skubitz, K.M. Cardiotoxicity Monitoring in Patients Treated with Tyrosine Kinase Inhibitors. Oncologist 2019, 24, e600-e602. [CrossRef]

119. Rao, V.U.; Reeves, D.J.; Chugh, A.R.; O'Quinn, R.; Fradley, M.G.; Raghavendra, M.; Dent, S.; Barac, A.; Lenihan, D. Clinical Approachto Cardiovascular Toxicity of Oral Antineoplastic Agents: JACC State-of-the-Art Review. J. Am. Coll. Cardiol. 2021, 77, 2693-2716. [CrossRef]

120. Cortes, J.E.; Kim, D.W.; Kantarjian, H.M.; Brümmendorf, T.H.; Dyagil, I.; Griskevicius, L.; Malhotra, H.; Powell, C.; Gogat, K.; Countouriotis, A.M.; et al. Bosutinib versus Imatinib in Newly Diagnosed Chronic-Phase Chronic Myeloid Leukemia: Results from the BELA Trial. J. Clin. Oncol. 2012, 30, 3486-3492. [CrossRef]

121. Khoury, H.J.; Gambacorti-Passerini, C.; Brümmendorf, T.H. Practical Management of Toxicities Associated with Bosutinib in Patients with Philadelphia Chromosome-Positive Chronic Myeloid Leukemia. Ann. Oncol. 2018, 29, 578-587. [CrossRef]

122. Cortes, J.E.; Jimenez, C.A.; Mauro, M.J.; Geyer, A.; Pinilla-Ibarz, J.; Smith, B.D. Pleural Effusion in Dasatinib-Treated Patients with Chronic Myeloid Leukemia in Chronic Phase: Identification and Management. Clin. Lymphoma Myeloma Leuk. 2017, 17, 78-82. [CrossRef] [PubMed]

123. Caocci, G.; Mulas, O.; Bonifacio, M.; Abruzzese, E.; Galimberti, S.; Orlandi, E.M.; Iurlo, A.; Annunziata, M.; Luciano, L.; Castagnetti, F.; et al. Recurrent Arterial Occlusive Events in Patients with Chronic Myeloid Leukemia Treated with Second- and Third-Generation Tyrosine Kinase Inhibitors and Role of Secondary Prevention. Int. J. Cardiol. 2019, 288, 124-127. [CrossRef] [PubMed]

124. Choueiri, T.K.; Schutz, F.A.B.; Je, Y.; Rosenberg, J.E.; Bellmunt, J. Risk of Arterial Thromboembolic Events with Sunitinib and Sorafenib: A Systematic Review and Meta-Analysis of Clinical Trials. J. Clin. Oncol. 2010, 28, 2280-2285. [CrossRef] [PubMed]

125. Sternberg, C.N.; Szczylik, C.; Lee, E.; Salman, P.V.; Mardiak, J.; Davis, I.D.; Pandite, L.; Chen, M.; McCann, L.; Hawkins, R. A Randomized, Double-Blind Phase III Study of Pazopanib in Treatment-Naive and Cytokine-Pretreated Patients with Advanced Renal Cell Carcinoma (RCC). J. Clin. Oncol. 2009, 27, 5021. [CrossRef]

126. Qi, W.-X.; Min, D.-L.; Shen, Z.; Sun, Y.-J.; Lin, F.; Tang, L.-N.; He, A.-N.; Yao, Y. Risk of Venous Thromboembolic Events Associated with VEGFR-TKIs: A Systematic Review and Meta-Analysis. Int. J. Cancer 2013, 132, 2967-2974. [CrossRef]

127. Cabanillas, M.E.; Takahashi, S. Managingthe Adverse Events Associated with Lenvatinib Therapy in Radioiodine-Refractory Differentiated Thyroid Cancer. Semin. Oncol. 2019, 46, 57-64. [CrossRef]

128. Farge, D.; Debourdeau, P.; Beckers, M.; Baglin, C.; Bauersachs, R.M.; Brenner, B.; Brilhante, D.; Falanga, A.; Gerotzafias, G.T.; Haim, N.; et al. International Clinical Practice Guidelines for the Treatment and Prophylaxis of Venous Thromboembolism in Patients with Cancer. J. Thromb. Haemost. 2013, 11, 56-70. [CrossRef]

129. Streiff, M.B.; Agnelli, G.; Connors, J.M.; Crowther, M.; Eichinger, S.; Lopes, R.; Mc Bane, R.D.; Moll, S.; Ansell, J. Guidance for the Treatment of Deep Vein Thrombosis and Pulmonary Embolism. J. Thromb. Thrombolysis 2016, 41, 32-67. [CrossRef]

130. Citro, R.; Prota, C.; Resciniti, E.; Radano, I.; Posteraro, A.; Fava, A.; Monte, I.P. Thrombotic Risk in Cancer Patients: Diagnosis and Management of Venous Thromboembolism. J. Cardiovasc. Echogr. 2020, 30, S38-S44. [CrossRef]

131. Sonpavde, G.; Je, Y.; Schutz, F.; Galsky, M.D.; Paluri, R.; Rosenberg, J.E.; Bellmunt, J.; Choueiri, T.K. Venous Thromboembolic Events with Vascular Endothelial Growth Factor Receptor Tyrosine Kinase Inhibitors: A Systematic Review and Meta-Analysis of Randomized Clinical Trials. Crit. Rev. Oncol. Hematol. 2013, 87, 80-89. [CrossRef]

132. Bekaii-Saab, T.S.; Ou, F.-S.; Ahn, D.H.; Boland, P.M.; Ciombor, K.K.; Heying, E.N.; Dockter, T.J.; Jacobs, N.L.; Pasche, B.C.; Cleary, J.M.; et al. Articles Regorafenib Dose-Optimisation in Patients with Refractory Metastatic Colorectal Cancer (ReDOS): AR andomised, Multicentre, Open-Label, Phase 2 Study. Lancet Oncol. 2019, 20, 1070-1082. [CrossRef] 
133. Grothey, A.; Van Cutsem, E.; Sobrero, A.; Siena, S.; Falcone, A.; Ychou, M.; Humblet, Y.; Bouché, O.; Mineur, L.; Barone, C.; et al. CORRECT Study Group. Regorafenib Monotherapy for Previously Treated Metastatic Colorectal Cancer (CORRECT): An International, Multicentre, R andomised, Placebo-Controlled, Phase 3 Trial. Lancet 2013, 381, 303-312. [CrossRef]

134. Llovet, J.M.; Ricci, S.; Mazzaferro, V.; Hilgard, P.; Gane, E.; Blanc, J.-F.; de Oliveira, A.C.; Santoro, A.; Raoul, J.-L.; Forner, A.; et al. Sorafenib in Advanced Hepatocellular Carcinoma. N. Engl. J. Med. 2008, 359, 378-390. [CrossRef] [PubMed]

135. Zamorano, J.L.; Lancellotti, P.; Rodriguez Muñoz, D.; Aboyans, V.; Asteggiano, R.; Galderisi, M.; Habib, G.; Lenihan, D.J.; Lip, G.Y.H.; Lyon, A.R.; et al. ESC Scientific Document Group. 2016 ESC Position Paper on Cancer Treatments and Cardiovascular Toxicity Developed under the Auspices of the ESC Committee for Practice Guidelines: The Task Force for Cancer Treatments and Cardiovascular Toxicity of the European Society of Cardiology (ESC). Eur. Heart J. 2016, 37, 2768-2801. [CrossRef] [PubMed]

136. Iqbal, N.; Iqbal, N. Imatinib: A Breakthrough of Targeted Therapy in Cancer. Chemother. Res. Pract. 2014, 2014, 357027. [CrossRef] [PubMed]

137. Grela-Wojewoda, A.; Niemiec, J.; Sas-Korczyńska, B.; Zemełka, T.; Puskulluoglu, M.; Wysocki, W.M.; Wojewoda, T.; PacholczakMadej, R.; Adamczyk, A.; Mucha-Małecka, A.; et al. Adjuvant combined therapy with trastuzumab in patients with HER2-positive breast cancer and cardiac alterations: Implications for optimal cardio-oncology care. Pol. Arch. Intern. Med. 2022, epub ahead of print. [CrossRef] 